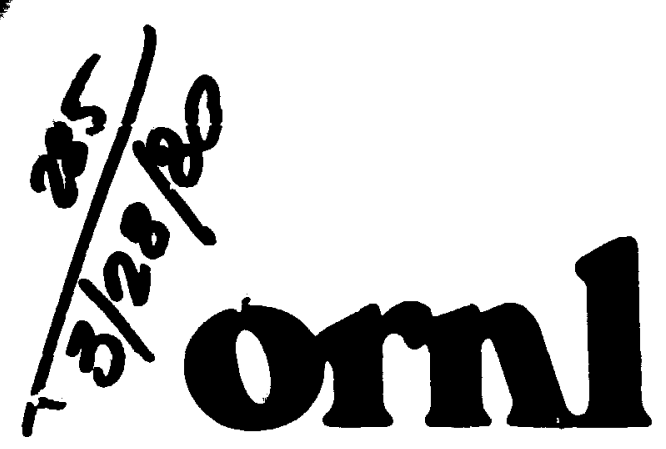

OAK RIDGE NATIONAL LABORATORY

\section{UNION \\ CARBIDE}

DR. 971

ORNL-5459

\section{Radiological Survey of the Inactive Uranium-Mill Tailings at Green River, Utah}

\author{
F. F. Haywood \\ D. J. Christian \\ B. S. Ellis \\ H. M. Hubbard, Jr. \\ D. Lorenzo \\ W. H. Shinpaugh
}

MASTER
GJFFATEL BY

UNION TARBIOH COUPOURAIION FOS IHF UNITEOS SIATES IFPAYIMEN UI INEHGYY

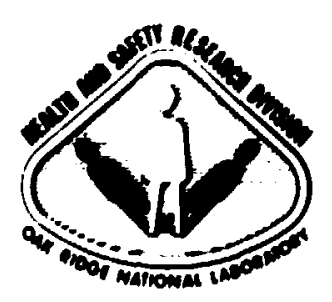


ORNL-5459

Dist. Category UC-41

Contract No. W-7405-eng-26

Health and Safety Research Division

RADIOLOGICAL SURVEY OF THE INACTIVE URANIUM-MILL

TAILINGS AT GREEN RIVER, UTAH

F. F. Haywood, D. J. Christian, B. S. Ellis, H. M. Hubbard, Jr., D. Lorenzo, and W. H. Shinpaugh

Date Published: March 1980

Appendix $I$ in this document is a direct reproduction of the Phase I interagency site visit prepared by Lucius Pitkin, Inc., under AEC Contrart AT(05-1)912.

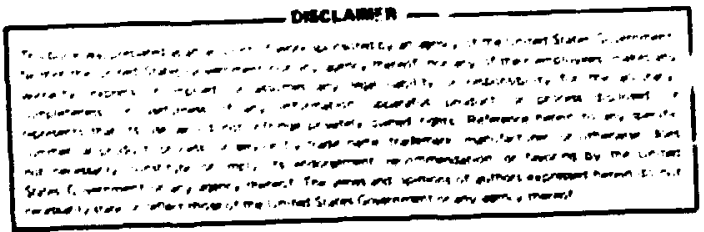

OAK RIDGE NATIONAL LABORATORY

Oak Ridge, Tennessee 37830

operated by

UNION CARBIDE CORPORATION

for the

DEPARTMENT OF ENERGY 


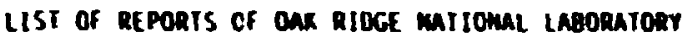
RAIOLOGICAL SURVEYS AI ImACTIVE URANIUA-MILL SITS

Mmor

1

\section{Iitle}

Assessecent of Raviological Inoct of the Inactive UraniumMill Iailings Pile at Salt lake City utah

Assessent of the Radiological Inpact of the Inactive Uraniur Mill Tailings at Shiprock. New Hexico

Assessent of the Radiological Impact of the Inactive Uraniur Mill Tzilings at Mexican Hat, Utah

Assessment of the Radiological Impact of the Inactive Uraniur nill Jailings Piles at bonument Valley. Arizco

Radiological Survey of the Inactive Uranim-Mill Tailings at Iuta City. Arizona

Radiological Survey of the Inactive Uraniun-kill Tailinys at Turango. Celorado

Radiological Survey of the Inactive Uranium-Mill Iailings at Slick Rock. Colorado

Aadiological Survey of the Inactive Uranium-Mill Tailings al Gunison. Colorado

Radiological Survey of the Inactive Uranico-Mill Tailings at Meurita. Colorado

Radiological Survey of the Inactive Uranius-Mill Tailings at Rifle, Colorado

Radiological Survey of the Inactive Uranisa-Hill lailings at Aybell. Colorado

Assessent of the Radiological Impact of the Inactive UranisMill Tailings at Grand Junction. Colorado

Radiological Survey of the Inactive Uraniu-Mill Tailings at nubrosia lake. New Nexico

Radiological Survey of the Inactive Uranium-Mill Tailings at Green River, Utah

Radiological Survey of the Inactive Uranium-Hill Tailings at the Spook Sile. Converse County, Hyomin,

Radiological Survey of the Inactive Uranium-nill Iailings at Riverton. Wroming

Radiological Survey of the Inactive Uraniumill Tailings at falls City, Ioxas

Radiological Survey of the Inactive Uranium-Mill Tallings at Ray Point, Texas

Radiological Survey of the Inactive Uraniushill Tailings at Lakeview, Oregon

Radiological Survey of the Radioactive Sands and hesidues at Loman, Idaho
Report no.

oantmh-5251

0ant-5447

onent - 5448

onisl-5449

ans - 5450

0 oul-5451

OAn1 -5452

ORML-5453

apNL-545A

ORNL-5455

Dnul-5456

ORNL-5457

ORUL-5458

OPNL-5459

ORNL-5M60

$08 x\lfloor-5161$

ONNL-5462

oniv-5463

ORNL-5464

OANL-5N65 


\section{CONTENTS}

Page

LIST OF FIGURES ....................... iv

LIST OF TABLES ....................... . . v

ACKNOWLEDGEMENTS .................... vi

ABSTRACT ................................ ix

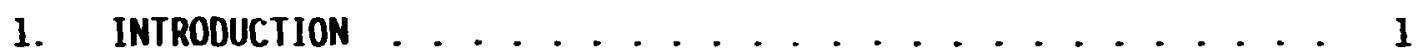

2. SITE DESCRIPTION .................... 1

3. SAMPLING TECHNIQUES AND RADIOLOGICAL MEASUREMENTS . . . . . 2

4. RESULTS OF MEASUREMENTS . . . . . . . . . . . . 2

4.1 Background Radisactivity .............. 4

4.2 Direct Gamna-Ray Exposure Rates . . . . . . . . . . . 4

4.3 Radionuclide Concentrations in Surface Soil and Sediment Samples ............. 7

4.4 Radiochemical Analysis of Water Samples....... 12

4.5 Distribution of ${ }^{226} \mathrm{Ra}$ in Subsurface Soil and Tailings ..................... 12

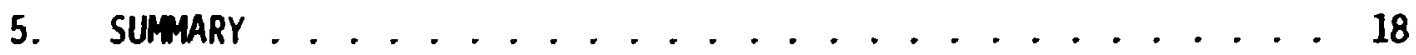

REFERENCES ........................ . . . 20

APPENDIX I, PHASE 1, Report on Conditions of Uranium Mill

Site and Tailings at Green River, Utah . . . . . . . . 21

APPENDIX II, Soil Sampling Techniques and Radiological

Measurements ................. . 37

APPENOIX III, Water Sampling and Analys is . . . . . . . . 51 


\section{LIST OF FIGURES}

Figure

Page

1 Aerial view of the Green River site and surrounding area ......................... 3

2 Locations of background external gamma measurements and background surface soil samples ....... 5

3 External gamma exposure rates $1 \mathrm{~m}$ above the ground.... 8

4 Locations and identifications of environmental

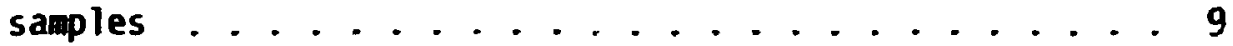

5 Locations of holes drilled at the Green River site . . 14

6 Calculated concentration of ${ }^{226} \mathrm{Ra}$ in holes $1,3,4$, and $5 \ldots \ldots 15$

7 Calculated concentration of ${ }^{226} \mathrm{Ra}$ in holes $2,6,7$, and $9 \ldots \ldots \ldots 16$

8 Calculated concentration of ${ }^{226}$ Ra in holes 10,11 , 12 , and $13 \ldots \ldots 17$ 


\section{LIST OF TABLES}

Table

Page

1 Background gamma-ray exposure rates and concentration of nuclides in surface soil samples around Green River, Utah .................6 6

2 Concentration of ${ }^{226} \mathrm{Ra}$ in surface soil and sediment samples at the Green River, Utah, site .......... 10

3 Concentration of ${ }^{226} \mathrm{Ra}$ in water and water sediment samples ................. 13 


\section{ACKNOWLEDGEMENTS}

The authors of this series of reports wish to express their deep appreciation to the following persons: to L. J. Deal and R. H. Kennedy, Department of Energy, Washington, D. C., for iheir encouragement and suoport during the field operations phase of this project; to Dr. Charles $\mathrm{d}$ i Barton of Sience Appiications, Inc. (SAI), Oak Ridge, for his diligent work in preparing, under subcontract, the drafts of this series, and to Wilma Minor, a?so of SAI for typing the manuscripts; to the many members of the Health and Safety Research Division who provided technical reviews of the individual reports; to Jenny Vinson, Health and Safety Research Division iechnical Editor, special thanks is extended for her careful review of each manuscript, especizlly for helping ensure that a uniform format was followed; to Dr. Barry Berven for his assistance in organizing the final drafts. Appreciation is extended to John 6 . Themelis and Frank McGinley, Department of Eiergy, Grand Junction Operations office, for their support and advice during the conduct of this project; to Charles z-unner, Bendix Field Engineering Company, Grand Junction, Colorado, for his assistance in arranging for the grinding of approximately 1600 soil samples which were collected during the project; also to Dr. Vern Rogers and his staff, Ford, Bacon and Davis Utah Inc., for assistance during the field operations phase of this project. Finally, the authors wish to acknowledge the efforts of Mr. Ev Haldane, Department of Energy, Grand Junction, who was associated with the uranium-mill tailings program from its earliest days. Ev passed away suddeniy on June 30, 1979, and it is to his memory that this series of reports is dedicated. 


\title{
RADIOLOGICAL SURVEY OF THE INACTIVE URANIUM-MILL TAILINGS AT GREEN RIVER, UTAH
}

F. F. Haywood, D. J. Christian, B. S. Ellis, H. M. Hubbard, Jr., D. Lorenzo, and W. H. Shinpaugh

\begin{abstract}
The uranium-mill tailings at. Green River, Utah, are relatively low in ${ }^{226} \mathrm{Ra}$ content and concentration (20 $\mathrm{Ci}$ and $140 \mathrm{pCi} / \mathrm{g}$, respectively) because the mill was used to upgrade the uranium ore by separating the sand and slime fractions; most of the radium was transported along with the slimes to another mill site. Spread of tailings was observed in all directions, but near-background gamma exposure rates were reached at distances of 40 to $90 \mathrm{~m}$ from the edge of the pile. Water erosion of the tailings is evident and, since a significant fraction of the tailings pile lies in Brown's Wash, the potential exists for repetition of the loss of a large quantity of tailings such as occurred during a flood in 1959. In general, the level of surface contamination was low at this site, but sorre areas in the mill site, which were being used for nonuranium work, have gamma-ray exposure rates up to $143 \mu \mathrm{R} / \mathrm{hr}$.
\end{abstract}




\section{INTRODUCTION}

This is one of a series of reports on results of radiological surveys of uranium-mill tailings at inactive mill sites in the western United States. A list of all the reports in this series is found at the front of this report. The first four reports and report No. 12 include assesiments of iutential health effects resulting from radiation and radionu:lides from the tailings. The first report contains a discussion of modes of radiation exposure to individuals and to population groups resulting irom the radionuclides in tailings at uranium-mill sites and a survey of the pertinent literature. The present report on the inactive mill site 1.. Green River, Utah, presents the results of a radiclogical survey conducted in July 1976 in cooperation with an engineering team from Ford, Bacon and Davis Utah Inc. (FB\&OU), the architect-engineering company responsible for the Phase II engineering assessment of the sites considered in this series. Their report on this site has been published.' Results of a gamma radiation survey of this site [by the Environmental Protection Agency (EPA)] have also been published. ${ }^{2}$ The previously unpublished Phase I engineering report on the Green River site by Brown et al. is included in Appendix I. Several publications ${ }^{3-8}$ include discussions of the uranium-mill tailings problem and of the assessment of the radiological impact of these tailings.

\section{SITE DESCRIPIION}

A description of the inactive uranium-mill site near Green kiver, Utah, and a history of the operations at this site is included in the Phase I report (Appendix I); similar information is furnished in the report by FB\&DU.' Only a brief summary of this information is included here.

The Green River mill was built in 1958 by Union Carbide Corporation (UCC) and operated by this company until the mill was shut down in 1961. During this operating period, the mill processed 166,000 metric tons of ore with an average $\mathrm{U}_{3} \mathrm{O}_{8}$ content of $0.29 \%$ (Appendix I). The mill product, an "ore concentrate," was shipped to UCC's Rifle, Colorado, plant 
for further treatment. Consequently, a large fraction of the radium shipped with raw ore to the Green River plant left with the concentrate. The tailings consist of the acid leached sand fraction, and they cover an area of approximately 3.2 ha ( 8 acres). The tailings $(112,000$ metric tons) contain approximately $20 \mathrm{Ci}$ of ${ }^{226} \mathrm{Ra}$ with an average ${ }^{226} \mathrm{Ra}$ concentration of $140 \mathrm{pCi} / \mathrm{g}$. The tailings pile has been graded and covered with soil averaging $15 \mathrm{~cm}$ (6 in.) in depth. Dikes have been constructed around the north and east edges of the pile to protect it from run-off water in Brown's Wash. According to a draving of the plant and mill site layout (Appendix I), a large part of the tailings pile is located in Brown's Wash. In August 1959, a flood washed away approximately 10\% of the originai tailings pile (Appendix I). An aerial view of the Green River site and surrounding area is shown in Fig. 1.

The tailings are surrounded by a barbed wire fence, and about $15 \%$ of the area is reported ${ }^{1}$ to be covered with weeds. The uranium-mill equipment was dismantled after production ceased; but the buildings are intact, and the area has been leased by UCC to Celesco, a contractor providing missile testing an ssembly services to the $U$. $S$. Department of Defense.

\section{SAMPLING TECHNIQUES AND RADIOLOGICAL MEASUREMENTS}

Sampling techniques, as well as equipment and metheds used in analyses of soil samples for radionuclides and in radiological monitoring, are Jescribed in Appendix II, while a description of the technique used to analyze water samples is contained in Appendix III.

\section{RESULTS OF MEASUREMENTS}

Measurements were made at the Green River site to determine: (1) background gamma radiation levels and backgrounc radionuclide concentrations in surface soil samples; (2) external gamma-ray exposure rates $1 \mathrm{~m}$ above the ground botil at the site and in the area immediately around the site; (3) radionuclide concentrations in surface soil, sediment, and water samples; and (4) the subsurface distribution cf ${ }^{226} R a$ in 
ORIL-Photo $0525-79$

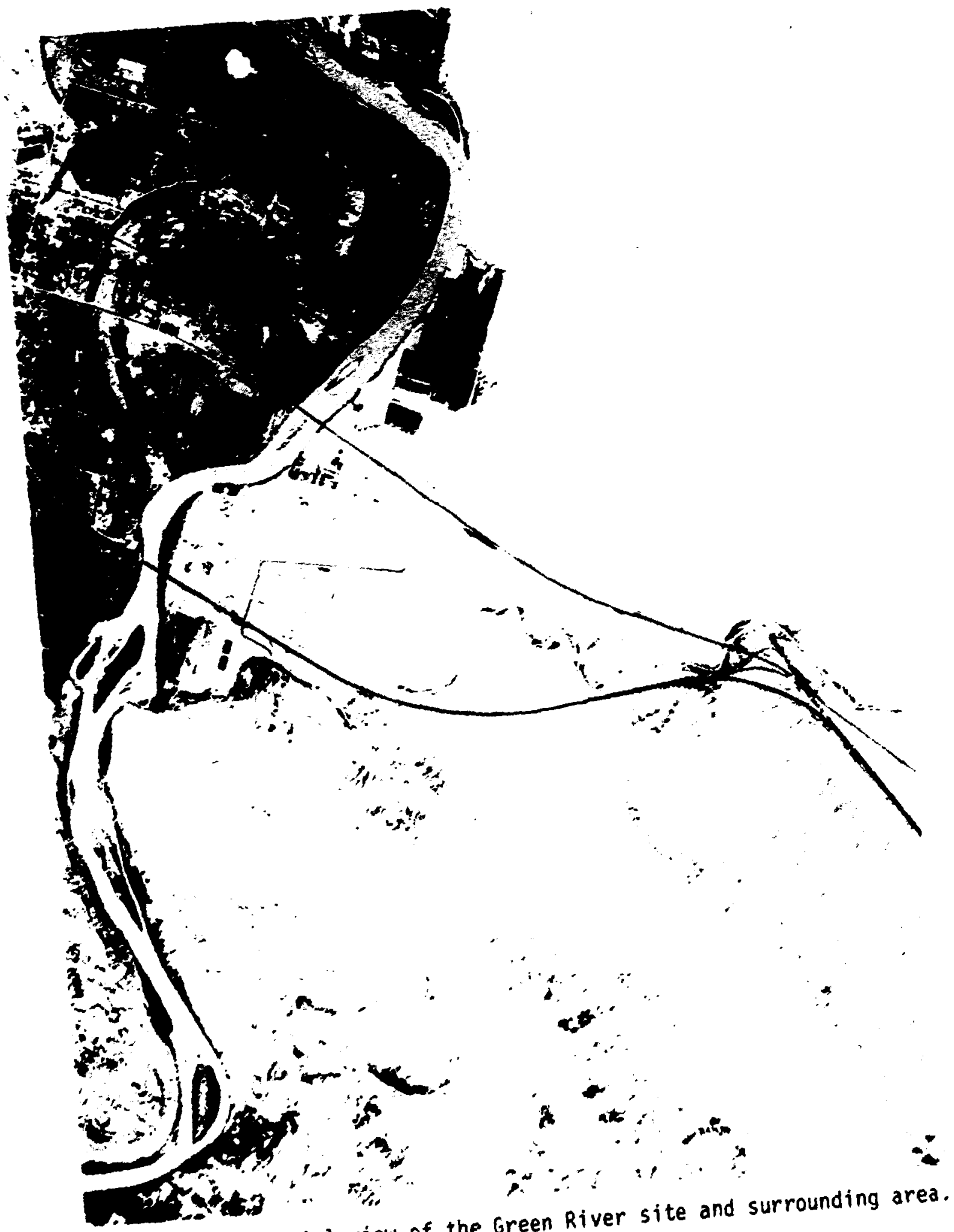

Fig. 1. Aerial view of the Green River site and surrounding area. Source: EG\&G, Inc. 
tailings and contaminated soil. Because of the short term of the survey, no attempts were mode at this site by the authors to measure the concentration of radon, radon daughters, or other airborne particulate matter. Results of the various types of measurements are discussed in separate sections below.

\subsection{Background Radioar.tivity}

Knowledge of background external gama radiai on levels and of background concentrations of radionuclides in the area soil is needed in order to evaluate the extent of spread of tailings from the site and to provide data needed in implementing clean-up procedures.

Locations are shown in Fig. 2 where background measurements were made of external gamma exposure rates $1 \mathrm{~m}$ above the ground and where surface soil sample: were obtained for analysis. Details of the sample sites and the results obtained are displayed in Table 1.

The data in Table 1 show a variation in measured values of the background gamma exposure rates $1 \mathrm{~m}$ above ground from 5 to $9 \mu \mathrm{R} / \mathrm{hr}$. The average value of $7 \mu \mathrm{R} / \mathrm{hr}$ corresponds to an annual background dose equivalent of $61 \mathrm{millirems.} \mathrm{The} \mathrm{average}{ }^{226} \mathrm{Ra}$ concentration in surface soil is $0.7 \mathrm{pCi} / \mathrm{g}$. There is not a good correlation between the direct gamma exposure rate and the ${ }^{226} \mathrm{Ra}$ concentration in surface soil, possibly due to the presence of other terrestrial radionuclides, failure to obtain representative soil samples, and poor measurement statistics resulting from the small amount of activity present.

\subsection{Direct Gamna-Ray Exposure Rates}

Measurements were made of direct gamma-ray exposure rates $1 \mathrm{~m}$ above the ground using the "Phil" gamma-ray dosimeter described in Appendix II. These measurements were mace, in general, at $23-m(25-y d), 46-m$ $(50-y d)$, or $91-m(100-y d)$ intervals: but man-made features such as fences and buildinss resulted in irregular measurement intervals in some places. 


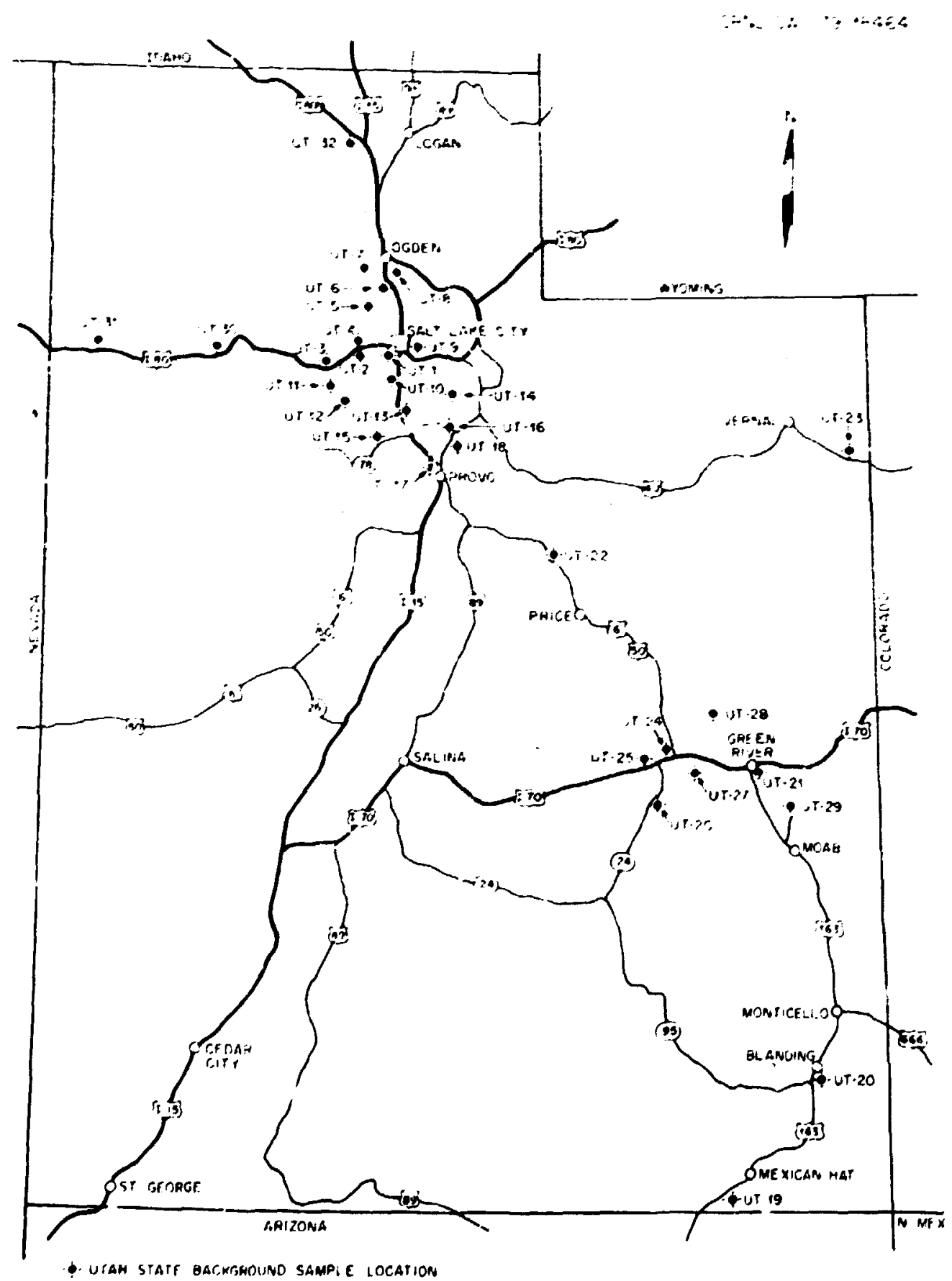

Fig. 2. Locations of tackground external gamma measurerients and background surface soil samples. 
Table 1. Background gamma-ray exposure rates and concentration of nuclides in surface soil samples around Green River, Utah

\begin{tabular}{|c|c|c|c|c|c|}
\hline \multirow[b]{2}{*}{$\begin{array}{l}\text { Sample } \\
\text { point }\end{array}$} & \multirow[b]{2}{*}{$\begin{array}{l}\text { Description of } \\
\text { sample location }\end{array}$} & \multirow{2}{*}{$\begin{array}{c}\text { External y } \\
\text { exposure } \\
\text { rate } \\
(\mu R / h r)\end{array}$} & \multicolumn{3}{|c|}{$\begin{array}{c}\text { Nuclide concentration } \\
(\mathrm{p} C \mathrm{i} / \mathrm{g})\end{array}$} \\
\hline & & & ${ }^{22}{ }^{6} \mathrm{Ra}$ & $232 \mathrm{Th}$ & $238 \mathrm{U}$ \\
\hline UT25 & $\begin{array}{l}\text { Junction of } \mathrm{Rt} 245 \text { and } I-70 \\
219 \mathrm{~km} \text { west of Green River }\end{array}$ & 5 & 1.0 & $b$ & 0.3 \\
\hline UT26 & On Rt $245221 \mathrm{~km}$ south of $1-70$ & 7 & 0.5 & 0.3 & 0.2 \\
\hline UT27 & $\begin{array}{l}\text { End of Twist Gap Road } \sim 16 \mathrm{~km} \\
\text { east of UT- } 26\end{array}$ & 6 & 0.5 & 0.6 & 0.3 \\
\hline UT28 & $\begin{array}{l}\text { Along Green River } \sim 19 \mathrm{~km} \text { north } \\
\text { of } 1-70\end{array}$ & 7 & 0.8 & 0.8 & 0.4 \\
\hline UT29 & $\begin{array}{l}\text { Entrance of Devils Garden, } \\
\text { Arches National Monument }\end{array}$ & 9 & 0.9 & $b$ & 0.7 \\
\hline Average & & 7 & 0.7 & 0.6 & 6.4 \\
\hline
\end{tabular}

${ }^{a}$ One meter above the ground.

${ }^{b}$ This nuclide not measured. 
Uata obtained at this site are displayed in Fig. 3. The data in Fig. 3 indicate moderately low gamma-ray exposure rates throughout the area with a maximum of $143 \mu \mathrm{R} / \mathrm{hr}$ at the mill site. The average for both the tailings area and the fenced mill site is $25 \mu \mathrm{R} / \mathrm{hr}$. There is little difference in the general level of gamma exposure rate above the tailings area and in the other parts of the site. Off-site measurements of the above-ground gamma exposure rates in $\mathrm{Fig}$. 3 show that $6 \mu \mathrm{R} / \mathrm{hr}$ was reached at approximately $90 \mathrm{~m}$ from the edge of the pile toward the east and south. Toward the north, the lowest measurement observed was $12 \mu R / h r$ at $60 \mathrm{~m}$ from the tailings, the end of the traverse in this direction. In the western direction, the $6 \mu \mathrm{R} / \mathrm{hr}$ exposure rate was reached at $38 \mathrm{~m}$ from the edge of the tailings pile while even lower measurements were obtained further west.

The data in Fig. ? show that there are several locations outside the fenced area (e. s., east and north of the tailings pile and east of the mill site) where exposure rates in the range 90 to $210 \mu \mathrm{R} / \mathrm{hr}$ were measured. Exposure at the higher rate for $2000 \mathrm{hr}$, a working year, would result in a dose equivalent of $420 \mathrm{millirem}$. This is below the IOCFR20 guide value for individuals in the general public, but it is higher than other proposed EPA and NRC standards for exposure of members of the public to low level radiation from nuclear fuel cycle activities.

\section{3 Radionuclide Concentrations in Surface Soil and Sediment Samples}

Analysis of soil and sediment samples for ${ }^{226}$ Ra supplements the measurement of above-ground gamma intensity in detecting the spread of uranium tailings or uranium ore particles. Surface and neär-surface soil and sediment samples obtained at locations shown in Fig. 4 were analyzed for ${ }^{226} \mathrm{Ra}$ by use of the technique and equipment described in Appendix 11. Results are displayed in Table 2.

The data in Table 2 confirm the belief, based on the external gamna measurements described in the previous section, that contamination at the Green River site is moderately low. The maximum observed ${ }^{226}$ Ra concentration in surface soil is $97 \mathrm{pCi} / \mathrm{g}$ at a point $366 \mathrm{~m}$ south of the 


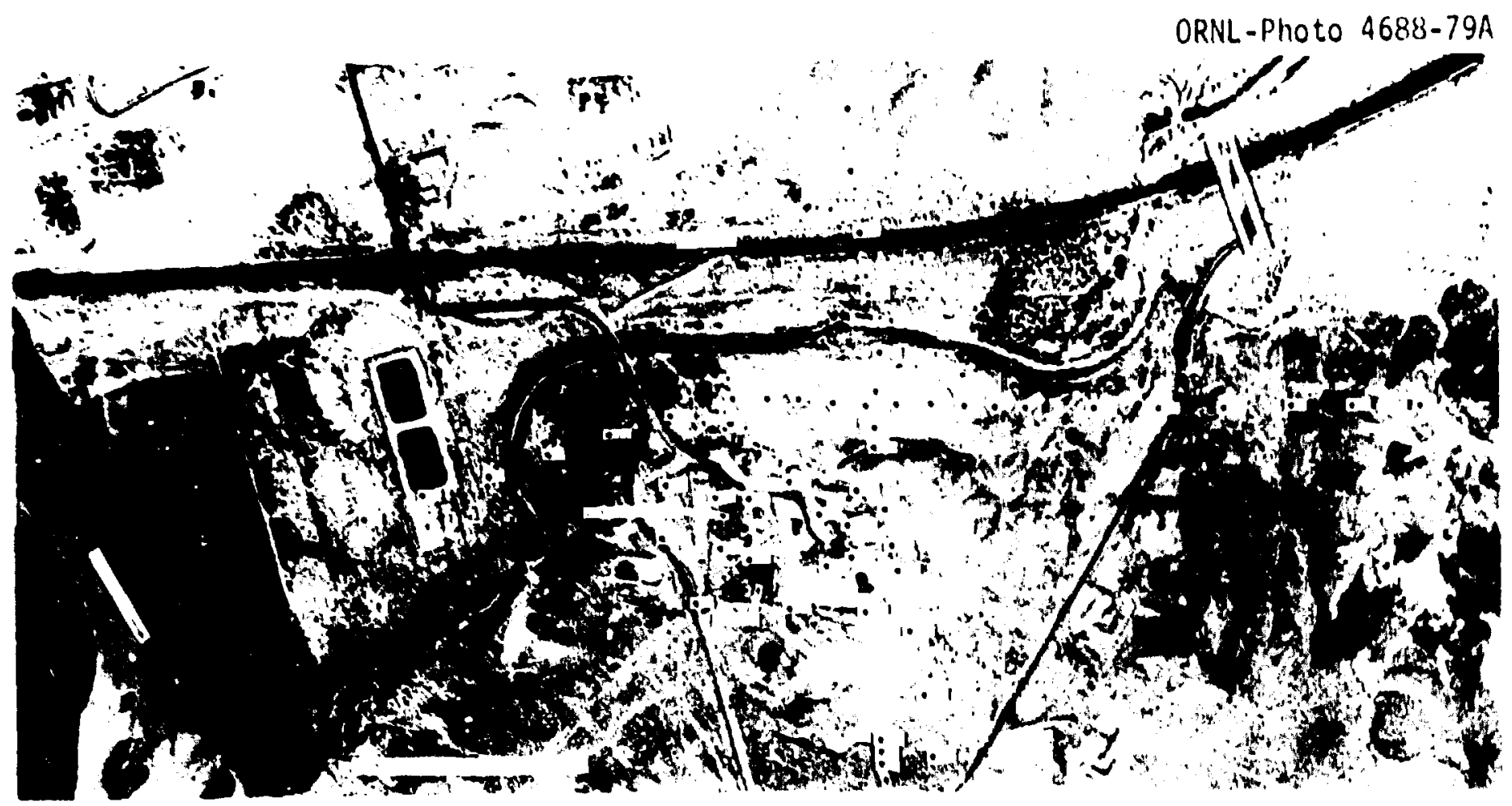

Fig. 3. External gamma exposure rates $1 \mathrm{~m}$ above the ground. Original photo by [G\&G, Inc. 


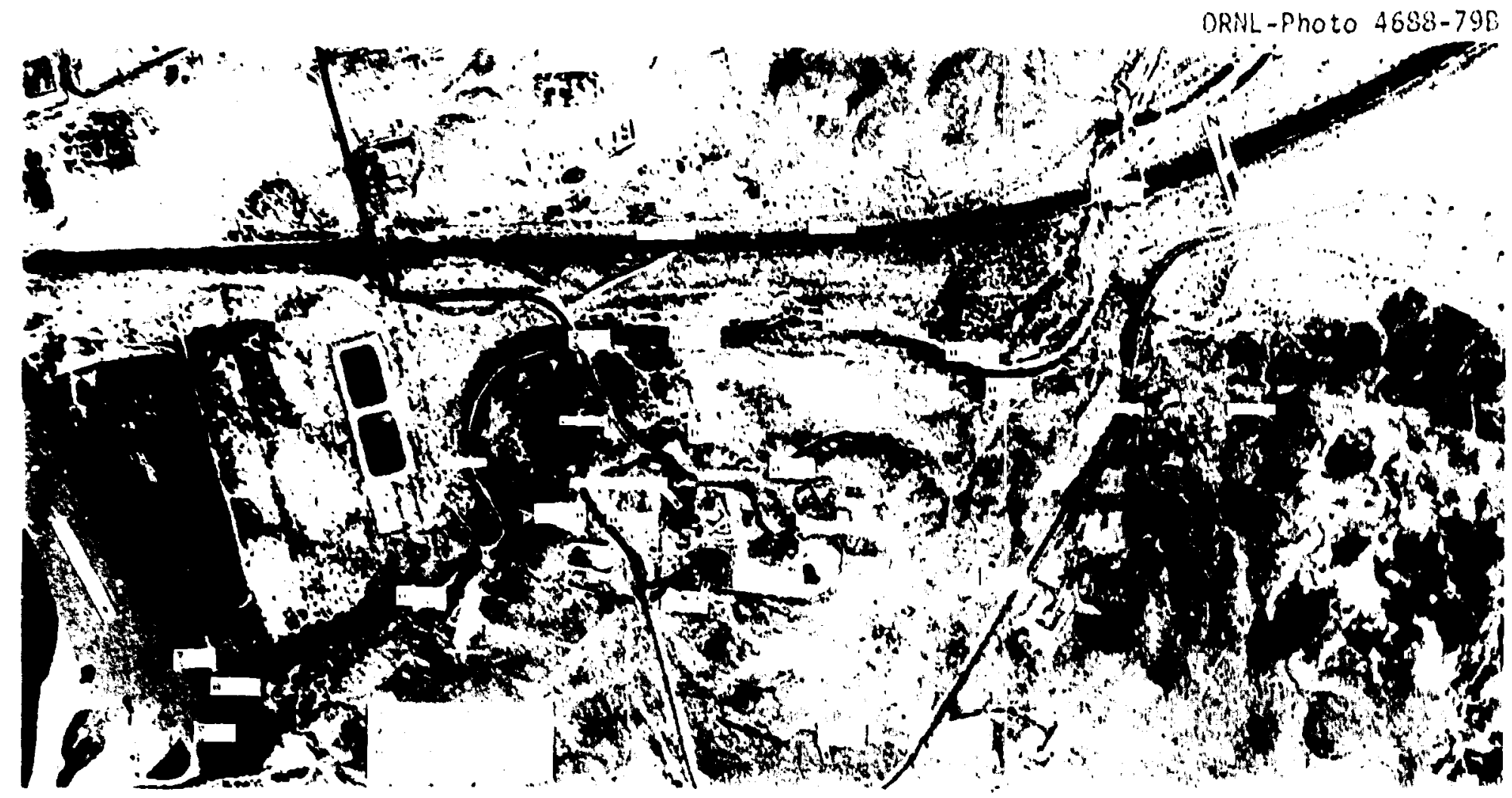

Fig. 4. Locations and identifications of environmental sampies. Original photo by EGra, Inc. 
Table 2. Concentration of $2 \geq 6$ Ra in surface soil and sediment samples at tho Green River, Utah, site

\begin{tabular}{|c|c|c|}
\hline $\begin{array}{c}\text { Sample } \\
\text { designation }\end{array}$ & Sample locat on and description & $\begin{array}{l}\text { Concentration } \\
\text { of } 226 R_{a} \\
(\mathrm{pCi} / \mathrm{g})\end{array}$ \\
\hline E200E & $\begin{array}{l}\text { Surface soil } 183 \mathrm{~m} \text { east frem base of } \\
\text { Tailings Pile (TP) }\end{array}$ & 6.5 \\
\hline E400E & Surface soil $366 \mathrm{~m}$ east from base of $\mathrm{TP}$ & 4.6 \\
\hline E600E & Surface soil $549 \mathrm{~m}$ east from base of IP & 3.2 \\
\hline E200W & Surface soil 183 west from base of TP & 12 \\
\hline E400W & Surface soil 366 west from base of TP & 0.9 \\
\hline E600W & Surface soil 549 m west from base of TP & 1.1 \\
\hline E200N & Surface soil $183 \mathrm{~m}$ north from base of TP & 12 \\
\hline E400N & Surface soil $366 \mathrm{~m}$ north from base of TP & 4.5 \\
\hline E200S & Surface soil $183 \mathrm{~m}$ south frow base of TP & 32 \\
\hline E400S & Surface soil $366 \mathrm{~m}$ south from base of TP & 97 \\
\hline E600S & Surface soil $549 \mathrm{~m}$ south from base of TP & 5.6 \\
\hline E800S & Surface soil $732 \mathrm{~m}$ south from base of TP & 2.2 \\
\hline EDW1 & $\begin{array}{l}\text { Surface sadiment from dry wash at north- } \\
\text { east. corner of fence around mill complex }\end{array}$ & 25 \\
\hline EDW2 & $15 \mathrm{~cm}$ below surface at EOWI & 15 \\
\hline EDW3 & $\begin{array}{l}\text { Surface soil from flat dry wash area } \\
23 \text { west of fence corner around TP }\end{array}$ & 82 \\
\hline EDW4 & $15 \mathrm{~cm}$ below surface at EDW3 & 9.2 \\
\hline EDW5 & $\begin{array}{l}\text { Surface sediment from dry wash } 46 \mathrm{~m} \\
\text { west of north fence of bunker area } \\
\text { SE of TP }\end{array}$ & 14 \\
\hline EDW6 & $15 \mathrm{~cm}$ below surface at EDW5 & 3.2 \\
\hline EDW7 & $\begin{array}{l}\text { Surface sediment from dry pond } 27 \mathrm{~m} \\
\text { east of TP fence }\end{array}$ & 110 \\
\hline
\end{tabular}


Table 2 (Continued)

\begin{tabular}{|c|c|c|}
\hline $\begin{array}{c}\text { Samfle } \\
\text { designation }\end{array}$ & Sámple location and description & $\begin{array}{l}\text { Concentration } \\
\text { of } 226 \mathrm{Ra} \\
(\mathrm{pCi} / \mathrm{g})\end{array}$ \\
\hline EDM8 & $15 \mathrm{~cm}$ below surface at EDW7 & 48 \\
\hline EOW9 & $\begin{array}{l}\text { Surface sediment from } 300 \mathrm{~m} \text { NE of } \\
\text { pile in dry wash under railroad }\end{array}$ & 0.90 \\
\hline EDW10 & $15 \mathrm{~cm}$ be low surface at EDW9 & 0.94 \\
\hline EOWl1 & $\begin{array}{l}\text { Surface sediment from dry wash at NE } \\
\text { corner of TP about } 32 \mathrm{~m} \text { from Hole } 6\end{array}$ & 0.85 \\
\hline EDW12 & $15 \mathrm{~cm}$ below surface at EOW11 & 1.1 \\
\hline EDW13 & $\begin{array}{l}\text { Surface sediment irom dry wash midway } \\
\text { of } T P \text { on north side }\end{array}$ & 1.0 \\
\hline EDW14 & $15 \mathrm{~cm}$ below surface at EDW13 & 1.1 \\
\hline EDW15 & $\begin{array}{l}\text { Surface sediment irom dry wash at } \\
\text { NW corner of TP }\end{array}$ & 0.9 \\
\hline EDW16 & $15 \mathrm{~cm}$ below surface at EDhi15 & 1.0 \\
\hline EDW17 & $\begin{array}{l}\text { Surface sediment from dry wash } ~ \\
\text { west of pile and due south of sewage } \\
\text { pond }\end{array}$ & 0.8 \\
\hline ENW18 & $15 \mathrm{~cm}$ below surface at EDW17 & 0.9 \\
\hline EDW19 & $\begin{array}{l}\text { Surface sediment from dry wash } 3 \mathrm{~m} \\
\text { before confluence with Green River }\end{array}$ & 1.2 \\
\hline EDW20 & $15 \mathrm{~cm}$ below surface at EDW19 & 1.2 \\
\hline EDW21 & $\begin{array}{l}\text { Surface sedimerit from dry wash west side } \\
\text { of road across from NW corner of fence } \\
\text { around mill site below drainage tile }\end{array}$ & 11 \\
\hline EDW22 & $15 \mathrm{~cm}$ below surface at EDW21 & 9.9 \\
\hline EOW23 & $\begin{array}{l}\text { Surface sediment frum ditch east side } \\
\text { of road at NW corner of fence around } \\
\text { mill site }\end{array}$ & 11 \\
\hline
\end{tabular}


edge of the tailings pile, indicating that some tailings material has been moved by wind. There are a number of dry-wash gullies around the tailings pile. Surface water run-off into these dry-washes represents one mechanism for tailings migration on the surface. Soil samples labelled EDW-1 through EDW-23 were collected in the dry-washes. 0ddnumbered samples represent surface samples and the immediately following even numbered sample was collected at a depth of $15 \mathrm{~cm}$. In most cases. the dry-wash samples were near che area average background concentration. niowever, most ail of the elevated ${ }^{226}$ Ra concentrations were found in samples within about $50 \mathrm{~m}$ from the edge of the tailings. One drywash sediment sample from near the east end of the tailings pile (EDW7) contained $110 \mathrm{pCi} / \mathrm{y}$. Two of the river bank sediment samples contained a near-jackground level of 22 risa, but cne contained approximately twice the background concentration. The sediment sample results show little evidence of current movement of tailings to the river.

\subsection{Radiochemical Analysis of Water Samples}

Water samples from locations shown in Fig. 4 were filtered, and the sediment samples were analyzed using the equipment and techriques described in Appendix II. The filtrate was analyzed by use of the technique described in Appendix III. REsults are displayed in Table 3, along with details of tne sample locations which are all in the Green River.

The data in Table 3 show that all the samples meet the EPA iriterim standard $^{9}$ for radium in drinking water $\left(5.0 \mathrm{pCi} / 1 \mathrm{iter}\right.$ for ${ }^{226} \mathrm{Ra}+$ $228 \mathrm{Ra}$ ).

\subsection{Distribution of ${ }^{226} R a$ in Subsurface Soil and Tailings}

Holes were drilled at the 13 locations shown in Fig. 5. Measurements of gamma rays in these holes as a function of deptin were made by FB\&DU and ORNL personnel using the apparatus described in Appendix II. Since subsurface gamma exposure is primarily due to ${ }^{226} \mathrm{Ra}$ and several of its daughters, it is possible to calibrate the instrument and, thus, 
13

Table 3. Concentration of $22^{\circ}$ Ra in water and water sediment samples

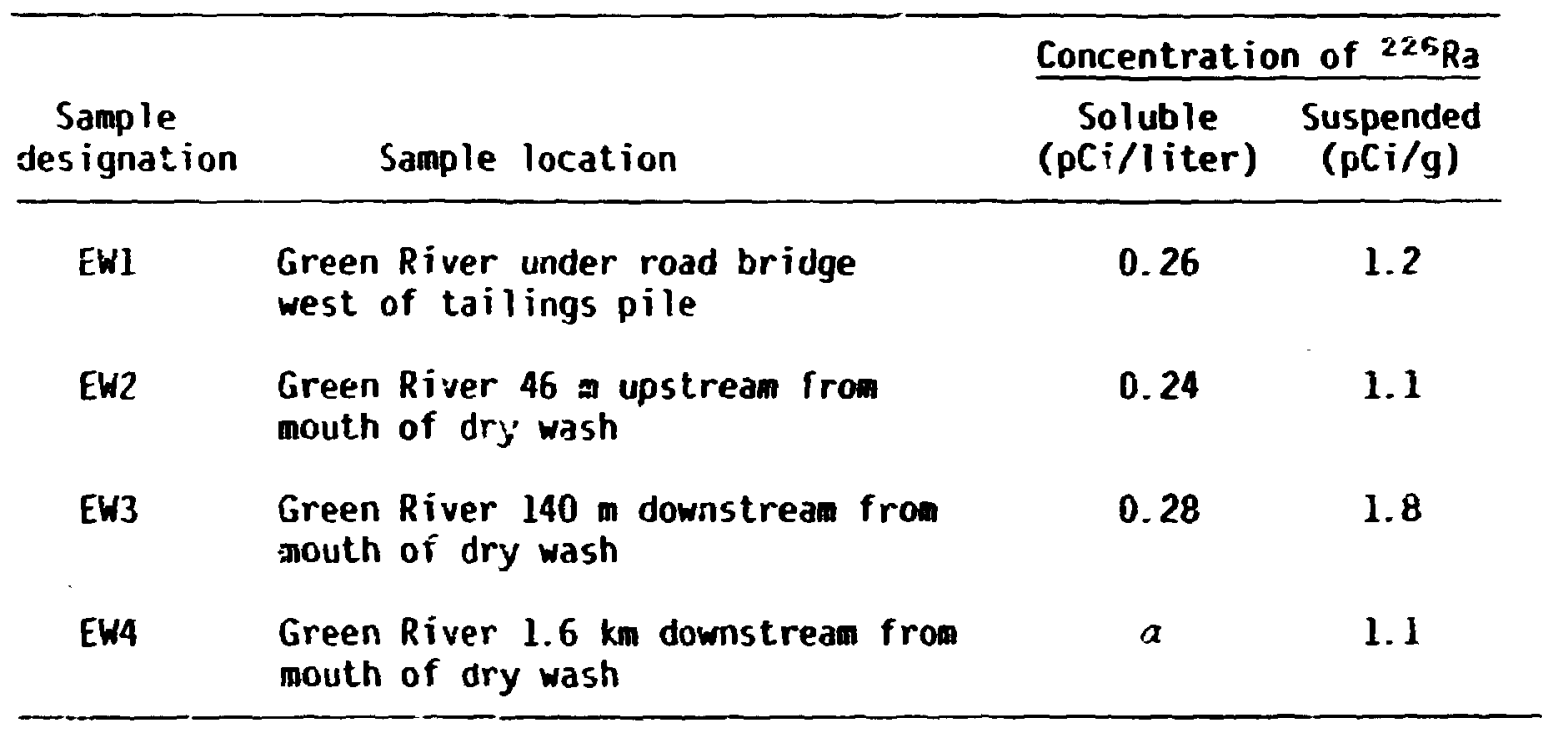

No data available. 


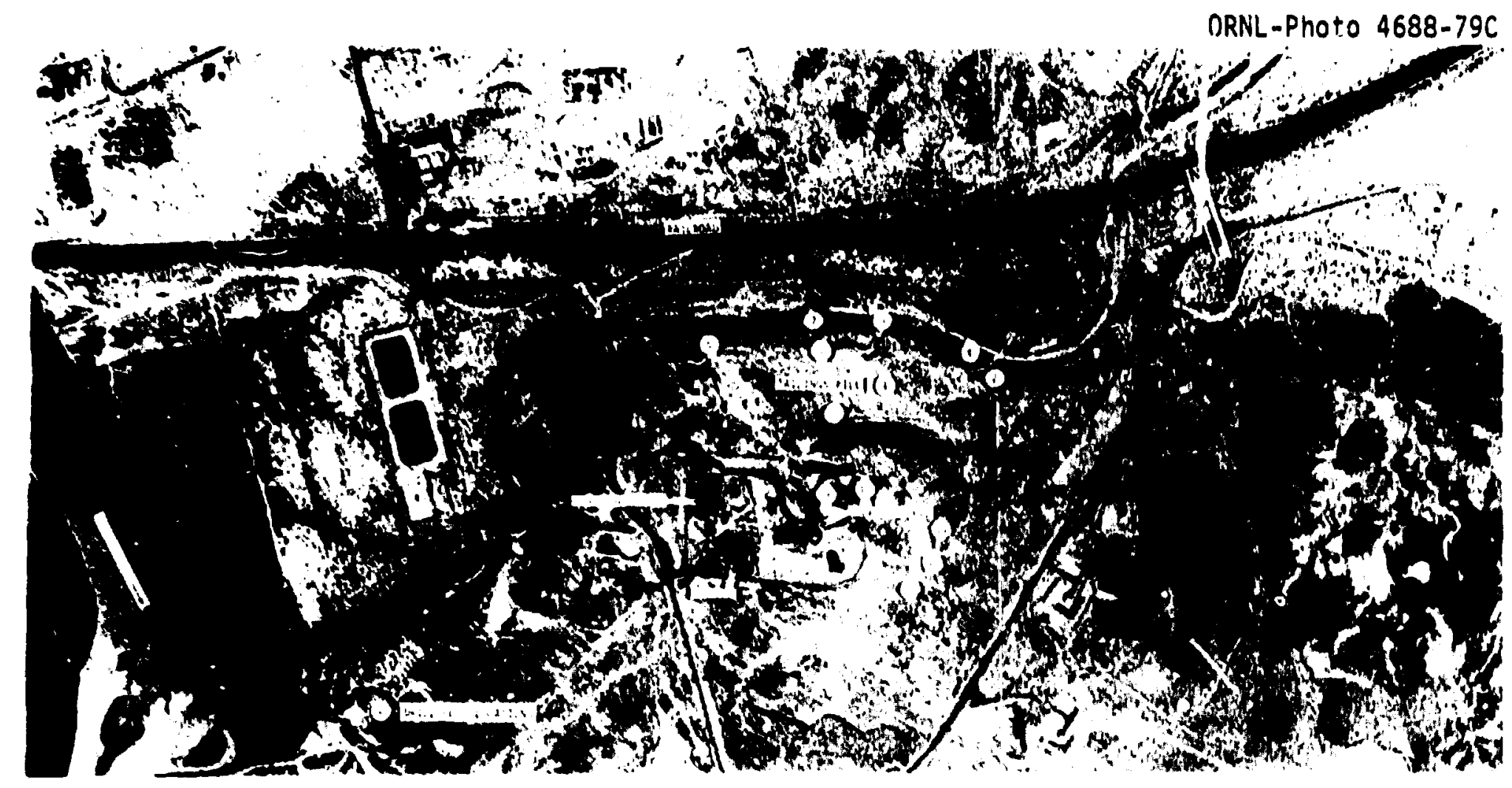

Fig. 5. Locations of holes drilled at the Green River site. Original photo by Eliki, Inc. 
ORNL. DWG 79-11031
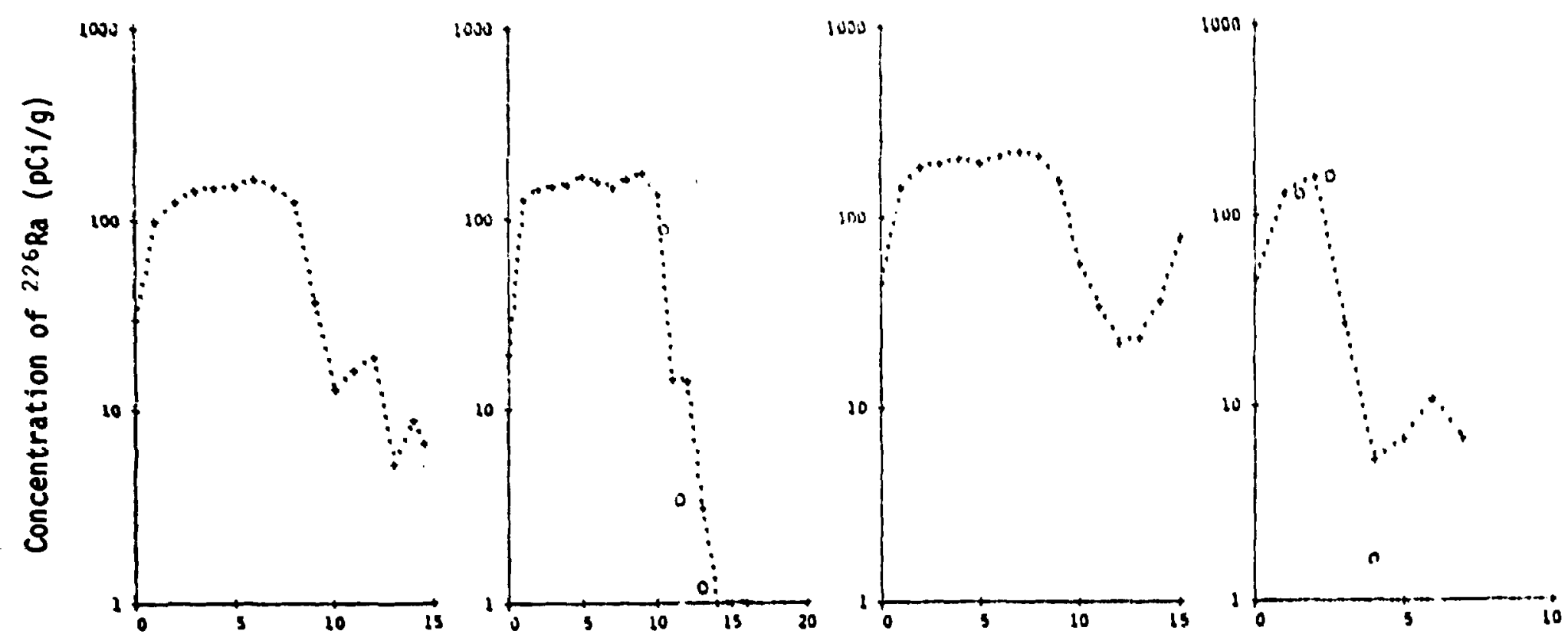

1

Depth below surface $(f t)$

3

4

5

Fig. 6. Calculated concentration of ${ }^{226} \mathrm{Ra}(\mathrm{pCi} / \mathrm{g})$ in holes $1,3,4$, and 5 . Values noted by circles in hcles 3 and 5 represent data from the analys is of individual suil samples. 
ORNL DWG 79-11032
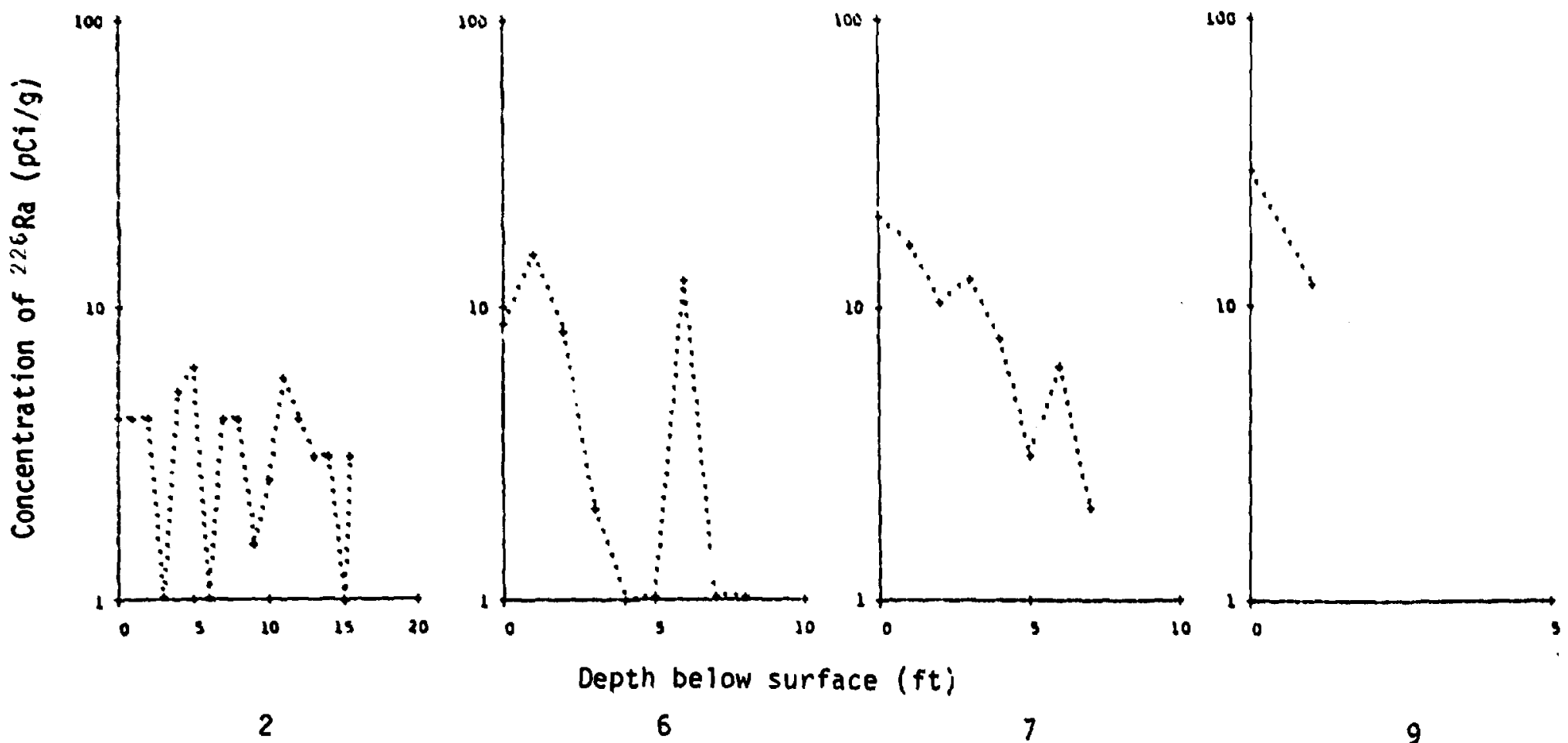

Fig. 7. Falculated concentration of $236 \mathrm{Ra}(\mathrm{pCi} / \mathrm{g})$ in holes $2,6,7$, and 9 , 
ORNL DWG $79-11033$
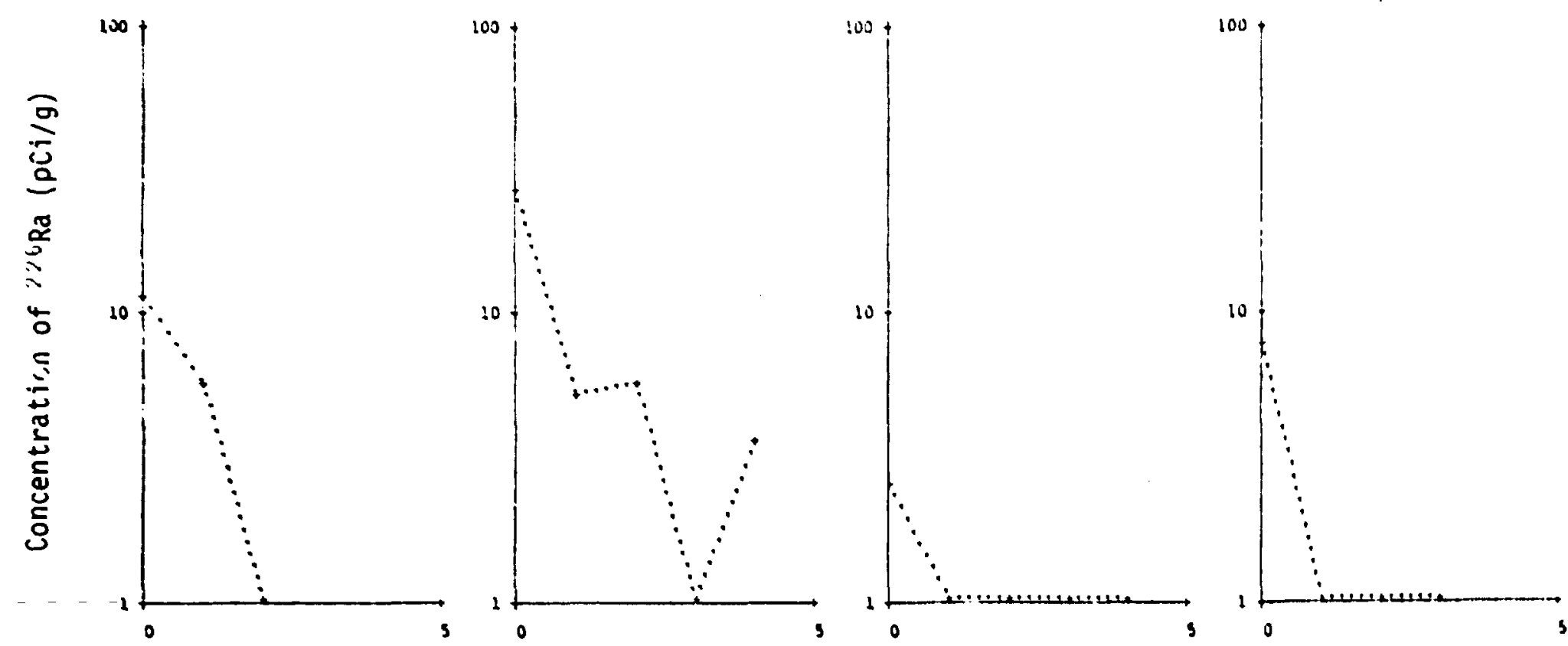

11

12

13

Fig. 8. Calculated concentration of ${ }^{2}{ }^{26} \mathrm{Ra}(\mathrm{pCi} / \mathrm{g})$ in holes $10,11,12$, and 13 , 
to convert the gamma-ray measuremerts to coriceritration of $22 \mathrm{u}^{\mathrm{R} a}$ by direct comparison between ${ }^{225}$ Ra concentration and yamma-ray measurements at locations where both quantities have been determined. The conversion was accomplished and the dica were plotted by use of a $9815 \mathrm{~A}$ HewlettPackard desk calculator and 19871 A Hewlett-Packard prinier. The available analytical data for sami?es taken from several holes (excluding hole composite samples) were plotted using the same equipment.

The calculated distribution of ${ }^{226} \mathrm{Ra}$ in subsurface soil and tailings at this site is displayed in Figs. 6-8, inclusive, omitting the plot for hole 8 where none of the measurements exceeded background. Sinilar graphs for holes 3 and 5 are included in another report. 1

Satisfaciory agreement is observed between calculated and measured values for ${ }^{226}$ Ra concentration for holes 3 and 5 , the only holes for which analytical data are available. As has been observed in similar plots of data frim other sites, the calculated ${ }^{226}$ a concentration in sections of holes where the concentration is low may be too high due to gamma-ray "shine" from an adjacent section of the hole and, possibly. due to smearing of concaminated soil on walls of the holes through the action of the auger bit, or due to contaminated soil that drops to the bottom of the hole.

\section{SUMMARY}

The uranium mill at the Green River site was operated for three years to projuce an "ore concentrate" that was transported to Rifle, Colorado, for further processing. Consequently, a large fraction of the ${ }^{226} \mathrm{Ra}$ brought to the plant in ore was removed in the plant product leaving sand fraction tailings with a low average ${ }^{226}$ Ra concentration (140 $\mathrm{pCi} / \mathrm{g})$ and a small inventory of this isotope $(20 \mathrm{Ci})$. This material was deposited in a tailings rile covering 3.2 ha ( 8 acres). The tailings pile has been stabilized, but only a small fraction of it is covered with vegetation. A significant fraction of the tailings pile is located in a dry wash area, but the pile is presently protected by dikes on the 
north and east sides. The original wil: buildings are intact; they are leased by the owner, Union Carbide Corporation, to Celesco, a government contractor.

Measurements of the external gamma exposure rate 1 in above ground showed moderataly low levels throughout the area with an average of $25 \mu R / h r$ above the tailings and at the mill site. A maximum measurement of $143 \mu \mathrm{R} / \mathrm{hr}$, in the former mill area, was obtained. The off-site measurements indicate spread of tailings in all directinns with near-background levels being reached at distances from approximateıy :0 to $90 \mathrm{~m}$. Some of the spots showing exposure rates in the range 90 to $210 \mu \mathrm{R} / \mathrm{hr}$ are outside the fenced areas. Anaiysis of surface soil samples supports the conclusion of limited spread of tailings and data from analysis of dry wash sediment samples helps to define the spread of tailings through water erosion There is little evidence that, under normal rainfall conditions, significar,t quantities of tailings currently reach the Green River. However, a flood in 1959 transported approximately 14,000 tons of the tailings.

Gamma monitoring data furnished by FB\&DU personnel were used to show the subsurface distribution of ${ }^{226}$ Ra in the holes drilled in the tailings and other parts of the site. The holes drilled in the tailings pile showed maximum ${ }^{226} \mathrm{Ra}$ concentrations of over $100 \mathrm{pCi} / \mathrm{g}$, but most of the other holes eniibited low levels of near-surface contamination. 


\section{REFERENCES}

1. Ford, Bacon and Davie Utah Inc., Phase II-Title I, Engineering Assessment of Iractive Uranizm :III Tailings, Freen Piver Site, Green River, Utah, GJT-14 (December 1977).

2. R. L. Douglas and J. M. Hans, Jr., Barma Nadiation Suryeys at Inactive Iranium leizl Sites, Technical lvote ORP/LV-75-5 (August 1975).

3. U. S. Atomic Energy Commission, Eviviromertal Sumez of the Uranium Fuel Cycle, WASH-1248 (April 1974).

4. U. S. Environmental Protection Agency, Environmental Analysis of the Uranium Fuel Cycle, Part I. Fuel Supply, PB-235804 (October 1973).

5. M. B. Sears, R. E. Blanco, R. C. Dahlmàn, G. S. Hill, A. D. Ryon, and J. P. Witherspoon, Coprelation of Radioactive Haste Treatment Costs and the Finvironmental Impact of haste ffiluents in the Huclear Fuel cycle for ise in Establishing "As-Iow-As-Practicabie" suives-rizling of tranizon Onos, ORNL-TM-4903, Vol. I (May 1975).

6. J. J. Swift, J. M. Hardin, and H. W. Calley, Potential Radiological Impact of Airborne Peleases and Direct Camma Padiation to Individuals Living Near Inactive Uranium laill :ailings Piles, EPA-520/1-76-001 (January 1976).

7. K. J. Schiager, "Analysis of Radiation Exposures on or Near Uranium Mill Tailings Piles," Radiol. Data Rep. 15, 411-25(1974).

8. W. A. Foldsmith, "Radiological Aspects of Inactive Uranium-Milling Sites: An Overview," Muc2. Safety 17 (6) 1976.

9. Code of Federal Regulations, Title 40, Part 141 (July 9, 1976). 


\section{APPENDIX I}

\section{PHASE I}

Report on Conditions of Uranium Mill Site and Tailings at Green River, Utah

Site visited May 15, 1974 by

Gordon T. Brown, Lucius Pitkin, Inc., (Contractor to USAEC), Grand Junction, Colorado, Jon Yeagley, Environmental Protection ńgency, Region VIII, Denver, Colorado, David E. Bernhardt, Environmental Protection Agency, Las Vegas, Nevada, Blaine Howard, Utah Division of Health, Salt Lake City, Utah.

This Phase I site investigation was conducted under a - cooperative agreement among the Atomic Energy Commis"sion, the Environmerital Protection Agency and the State of Utah. The report, prepared by Lucius Pitkin, Inc., under AEC Contract AT(05-1)912, is reproduced directly from the best available copy with color photographs attached to the original report changed to black and white. 


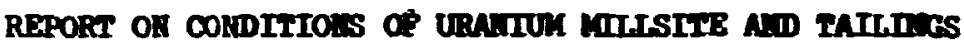
AT GREE RTER, UIA

\section{Introduction}

Pertinent information has been accunlated from avalable records of the $A B C$, EPA, the states and coupanies imrolved. An on-site visit was wade to notc current conditions, including the fillsite and the tailings disposal area, proximity to populated and industrialized areas, present ownership, and wether a need for corrective action exists. It is intended that this report will serve as a basis for deterwining the necessity of a detallej engineering assessuent (Fhase II).

This report on the site at Green River, Utah, was prepared jointly by the $A B C$, the EPA, and the State of Utah's Division of Health, Burironintal Health Administration.

\section{Summary and Conclusions}

The Green River, Utah, plant was operated by Unt on Carbide Corporation from March 1958 to January 1961 for the upgrading of ore from the uranium mines at Teuple Nountain. The upgraded "ore concentrate" was shipped by rail to Rifle, Colorado, for further processing.

The upgrading plant has been dismantled, but the buildings remain and are leased by Union Carbide Corporation to Celesco, a company which performs some missile assembly and testing functions under contract with the $U$. $S$. Department of Defense.

The tailings pile on a low:r bench about 200 feet from the plant site 18 estimated to contain 123,000 tons with an average grade of 0.03 percent $\mathrm{U}_{3} \mathrm{O}_{8}$. Because of the nature of the upgrading process, the tallings are afmost oll sand and the radium content is much lower than in ordinary uranium mill tallings. Union Carbide graded and covered the tallings and natural vegetation is becouing established.

As a result of the site visit and review of avilable information, it is concluded that the public bealth and economdc impacts of the following actions should be investigated in a further study of the Green RIver site:

I. Remove radioactive material from arrounding areas, return it to the tallings pile, and stabilize it. Evaluate need to decontaninate the milsite. 
II. Increase the stabilizing covering on the tie and coatour it across the slope to minimize erosion.

III. Inprove the riprap along Brown's Wash on the north side of the tailings pile and evaluate other steps to reduce possibility of erosion and flood damage.

IV. Evaluate radioactivity levels in the occupied buildings and millsite enclosure. Recomend correcti ve actions if indicated.

\section{Location}

The site of the Green River uraniu ore upgrading plant is at $38^{\circ} 59^{\prime}$ Horth latitude and $110^{\circ} 08^{\prime} 20^{\prime \prime}$ West longitude, in Section 15, Tounship 21 South, Range 16 East, Salt Lake Meridian, about a half aile east of the Green River and a wle east of the town of Green River, Uteh, just south of the DePis Rallroad and nearly a mile south of U. S. Highray 6 and 50 . The elevation is about 4,100 feet above sea level.

Owership

The Green River upgrading plant was built and operated by Union Carbide Corporation and the site and bulldings are still uned by Union Carbide.

\section{History of Operations}

The Green River plant was operated from March 1958 to January 1961 for the upgrading of ore from the uranium mines at Temple Nountain. During its three years of operation, 183,000 tons of ore averaging 0.29 percent $\mathrm{U}_{3}{ }_{\mathrm{B}}$ were fed to process in the Green River plant. The upgraded "ore concentrate" was shipped by rail to Rifle, Colorado, for further processing.

Figure 1 shows the layout of the plant and tailings area.

\section{Process Description}

The ore was sandstone loosely cenented with clay and asphaltic material, with part of the uranium intimately associa ted with the carbonaceous winerals. After crushing and grinding, the ore was screened, with minus 35 mesh material going to flotation and the plus 35 mesh material joining the flotation concentration to form a carbonaceous concentrate. The Notation tailings vere separated into sand and slime fractions, the sands were leached with acid, the leached slurry washed, and the opent sands ciscarded to the tallings area. The recovered slines and pregnant solution then joined with a portion of the inftial sliwe fraction. Any excess acid was neutralized with amonia. This wixed product plus the remainder of the primary slimes were th. dewatered and dried for shipment to the Rifle plant. I/ 


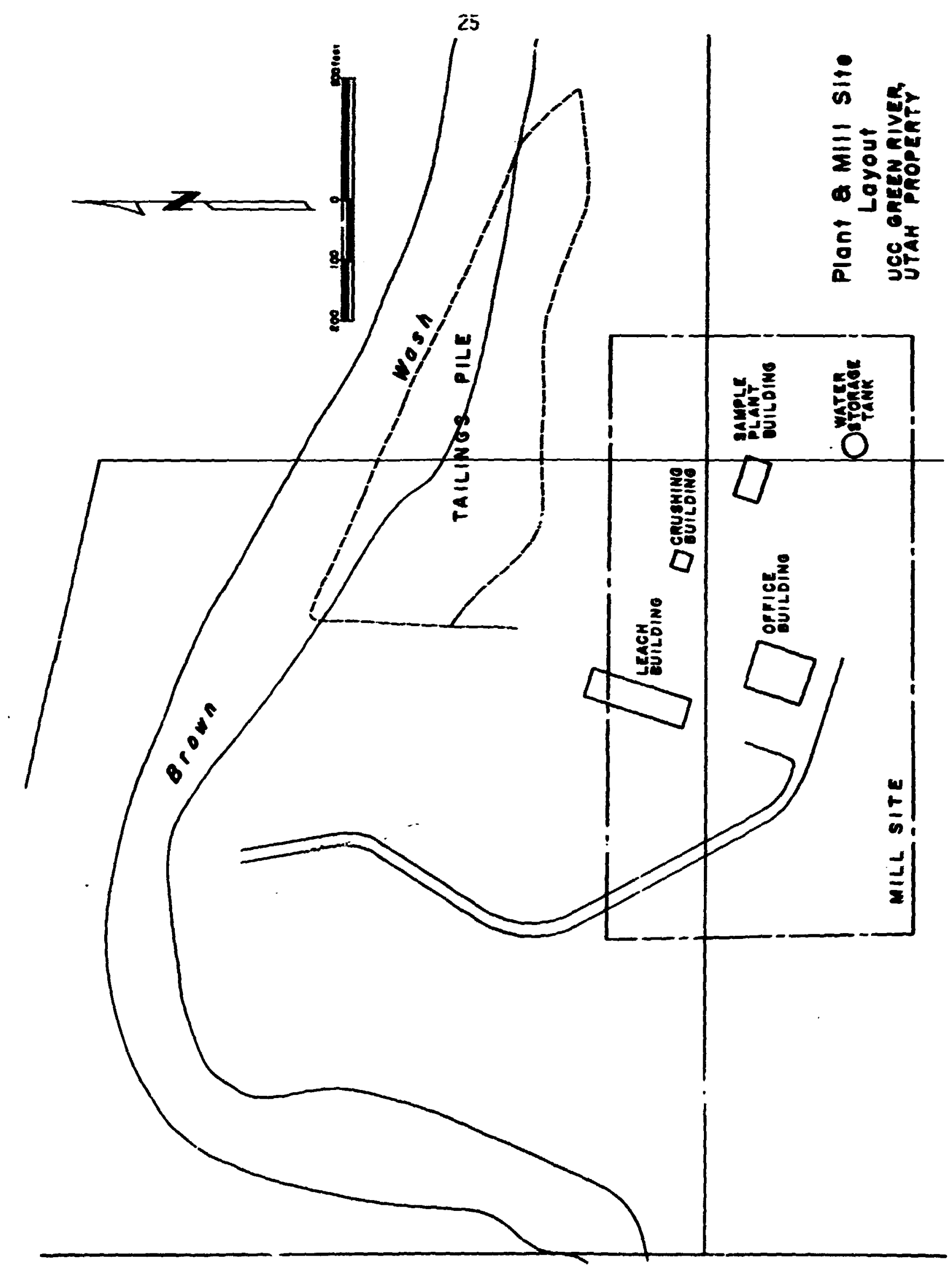




\section{Present Millsite}

Photograph 1 shows the site as it is nor.

The upgrading plant has been dismantled, but the buildings remain and are leased by Union Carbide Corporation to Celesco, a company which performs some missile essembly and testing nuctions under contract with the U. S. Department of Defense.

The tailings cover an area of about eight acres on a lcwer beach about 200 feet north of the plart site. (Fhotograph 2). The quanlity of tailines generated by the upgrading plant was estimated to be $13^{n}, 000$ tons, but since sowe of the material vas lost down Brown's Nash towerd the Green River during a flash flood the quantity remining is now stimated at 123,000 tons. Because of the nature of the upgrading process, the tailings are almost all sand, with an average $U_{3} \mathrm{O}_{8}$ content estimated to be 0.03 percent.

\section{Pmironmental Considerations}

There ere apparently no published rediation surveys of the Green River area. A very cursory survey by this tean and preliminary results from a current EPA gama radiation survey indicate general contamination in the millsite area (roughly I mR/hr around the ore weighing station and the ore bin ramp) and across the railroad track, which is about 400 feet north of the tailings pile.

Ho intentional removals of tailings from the pile are known to have occurred. Past repurts of the Federal Water Pollution Control Aduinistration indicate that tailings have been carried both by wind erosion and flood waters (August 1959) into Brown's Wash, which flows to the Green River. Results of samples frow the river apparentl:- Indicate that Ra-226 concentratj $x$ s are well within the guidelines. Bec use of the nature of the upgrading process used here, the Ra-226 concen ration in the remaining sand tallings is quite low, about $140 \mathrm{pCl}$ per gram. On this basis the Ra-226 contained in the talings is about 20 curies.

Celesco has about 25 people working 40 hours per week in the building on the former ufgrading plant site. There are storage facilities east of the site which are essentially unmanned and are visited only occasionally. The nearest dwellings are about a quarter mile north of the tallings pile where the White Sands Mssile Range has administrative offices and some on-base housing. The village of Blgin is about a half wile northwest of the pile. 
Union Carbile Corpa ation constructed dives on the east, north and west sides of the tailinge pile and it is contained by bigher ground on the south. Large rocks were placed on the east dike and part of the north jike to prevent further flood erosion. A diversion pond at the northwest corner is to prevent runoff from the pile from going into Brom 'I Uash.

The tailings pile was graded and covered with dirt taken from the hillside on the southeast and compacted to a depth of six inches. Sowe vegetation is becomins established on the soll cerer. It wes observed that wany of the machine tracks on the surface do not parallel the contours but run up and down the slope forming natural erosion chanpels. (Photograph 2). The pile slopes north toward Brown's Wash and sone runoff water erosion hes occurred. (Photograph 5). There also appears to be sone wind erosion.

The pile is well fenced (Thotographs 4 and 7) and adequately posted, Lhough the gates are not locked.

\section{Neteorology}

The average annual precipitation is about $s i x$ inches and the average annusi temperature is 2 bout $52^{\circ} \mathrm{F}$. The prevailing winds are from westerly directions ranging from north-northwest to south-southwest.

\section{Hydrology}

Flooding in Brom 's Wash hes been a problem in the past. Chonnel inprovements to handle noods in excess of 5,600 cubic feet per second would be necded to provide sufficient channel nepacity to accowodate runoff without erosion of the tailings. Dxtensive riprap and possibly channel deepening may be necessary. (Photographs 6 and 7).

Ground watcr in the area is not expected to be a problem. It is fairly deep and of poor quality and its widespread development is unlikely.

Diversions of potable water from the Green River are upstream from the tailings and not likely to be affected now or in the future.

\section{Site Visit}

The Green River site was visited on kay 15, 1974, by the followiag personnel (team) gutded by Bernie Lasson of celesco and Joe Hopkins of Union Carbide Corporation:

Cordrn T. Brom, Lucius PItkin, Inc., (Contractor to USABC), Grand Junction, Colorado, Jon Yeagley, Buvironmental Protection Agency, Region VIII, Denver, Colorado, David E. Bernhardt, Environwental Protection Agency, Las Vegns, Nevade,

Blaine Howard, Utah Division of Health, Snit Iake City, Utah. 
28

References 1. Herritt, Robert $C$., The Dxtractive Vetallurgo of Uraniug,
Co:orado Schos! of Mines Research Inst., Usabc Contract, 1371, pp. $271-273$.

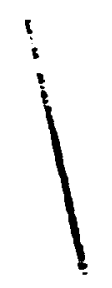

, 


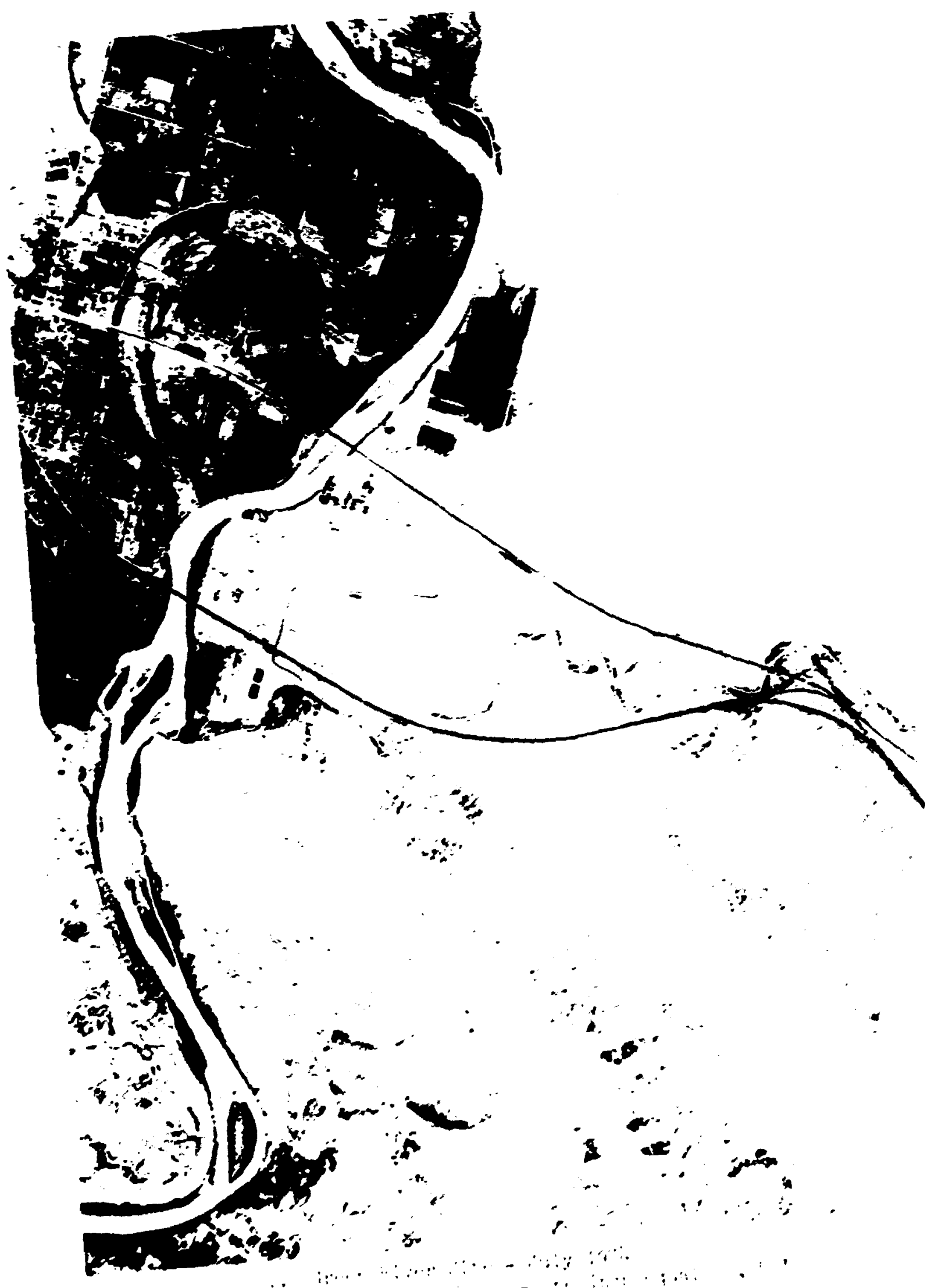




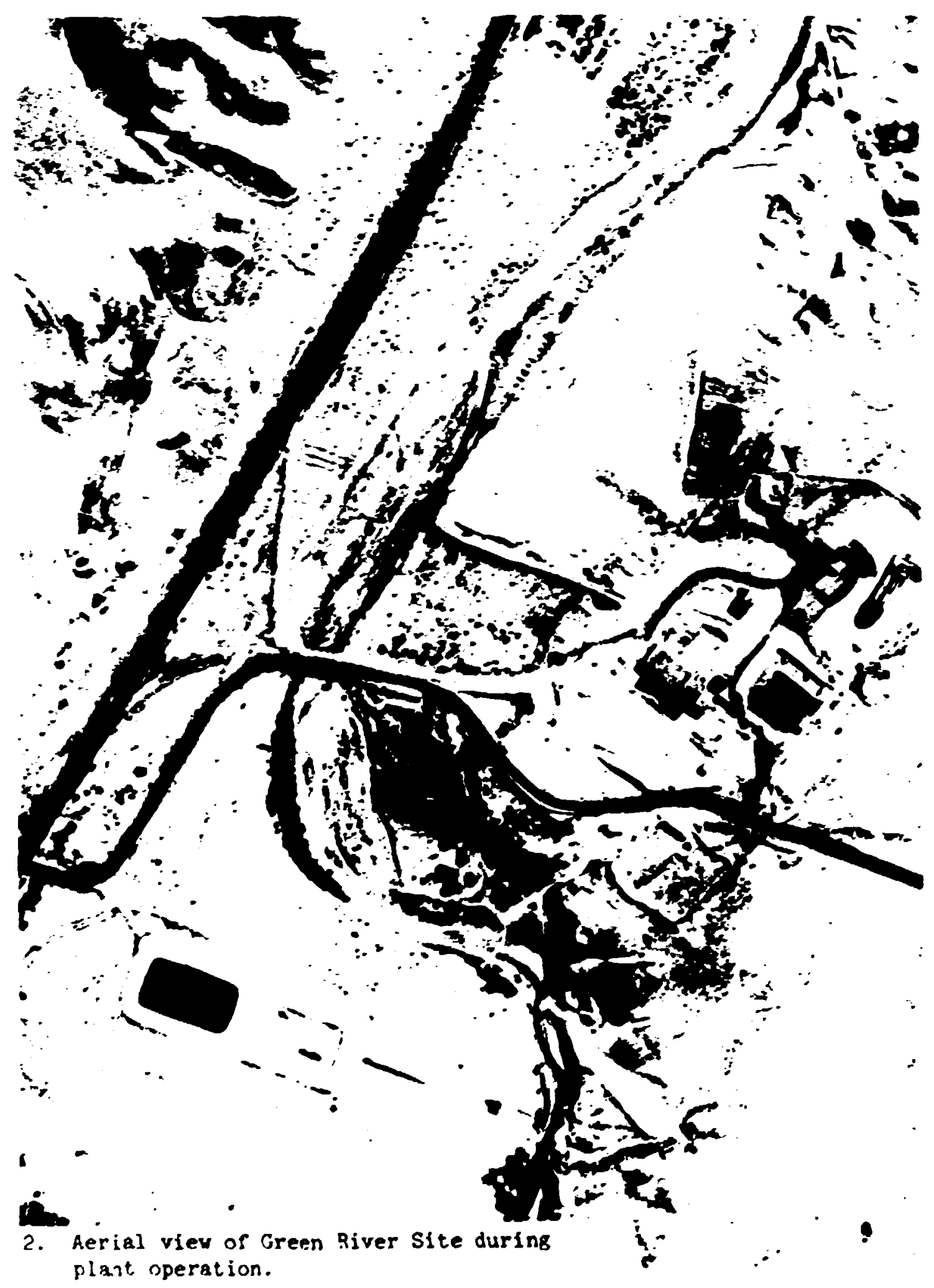

Grien RIVL - Ualon carbide corporation

Approzinate scale - one Inch epuale 360 feet 


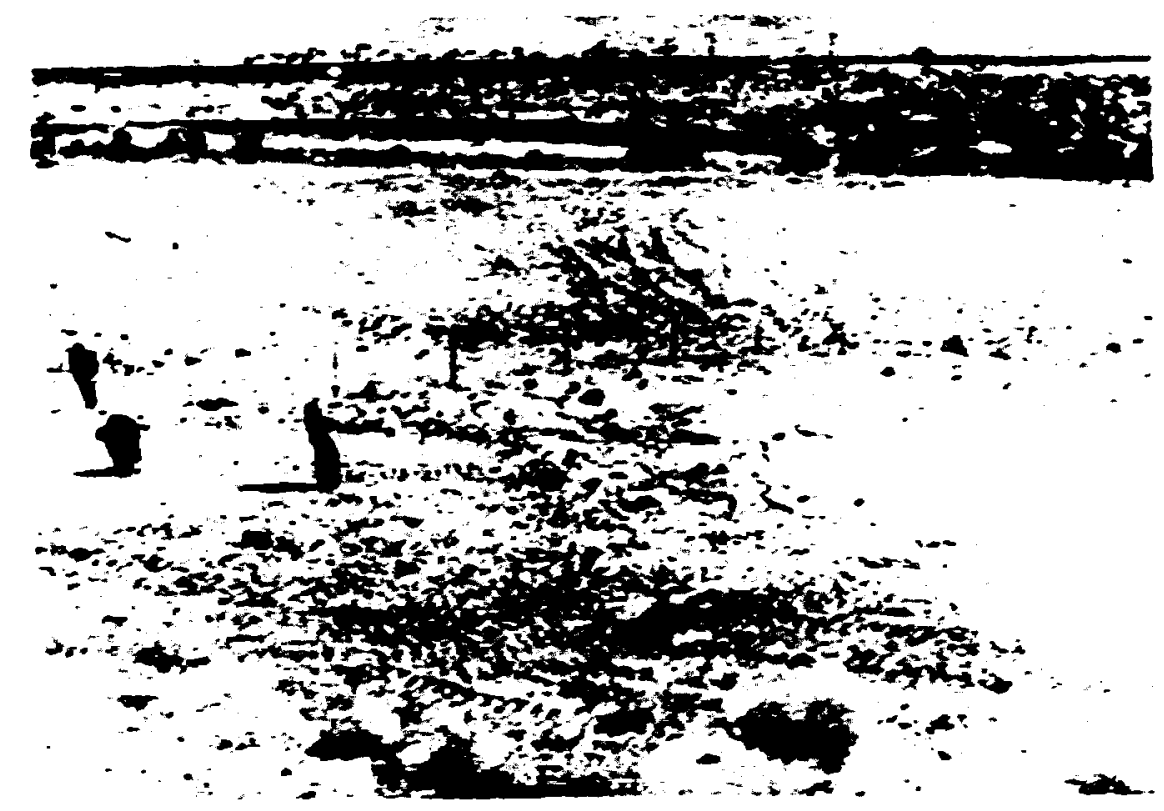

$\therefore$ Green Rivre tailings pile, bey'snd the fence. Brown's Whsa and DeRGW railroad in she backerolind. Lockilit ar.t.t.

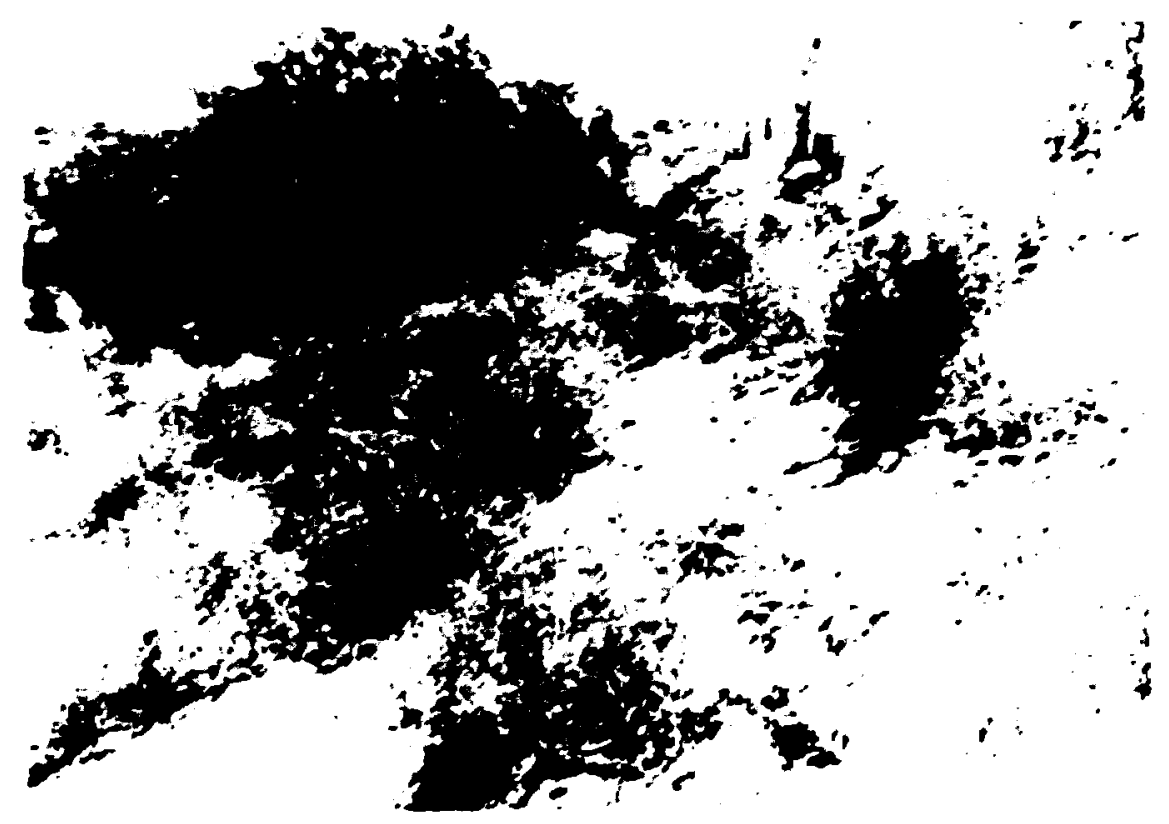

i. L :ok:an sout!nast from Brown': Wash to r.orthw'st cerner

s: Conc.'l inil inks aran. 


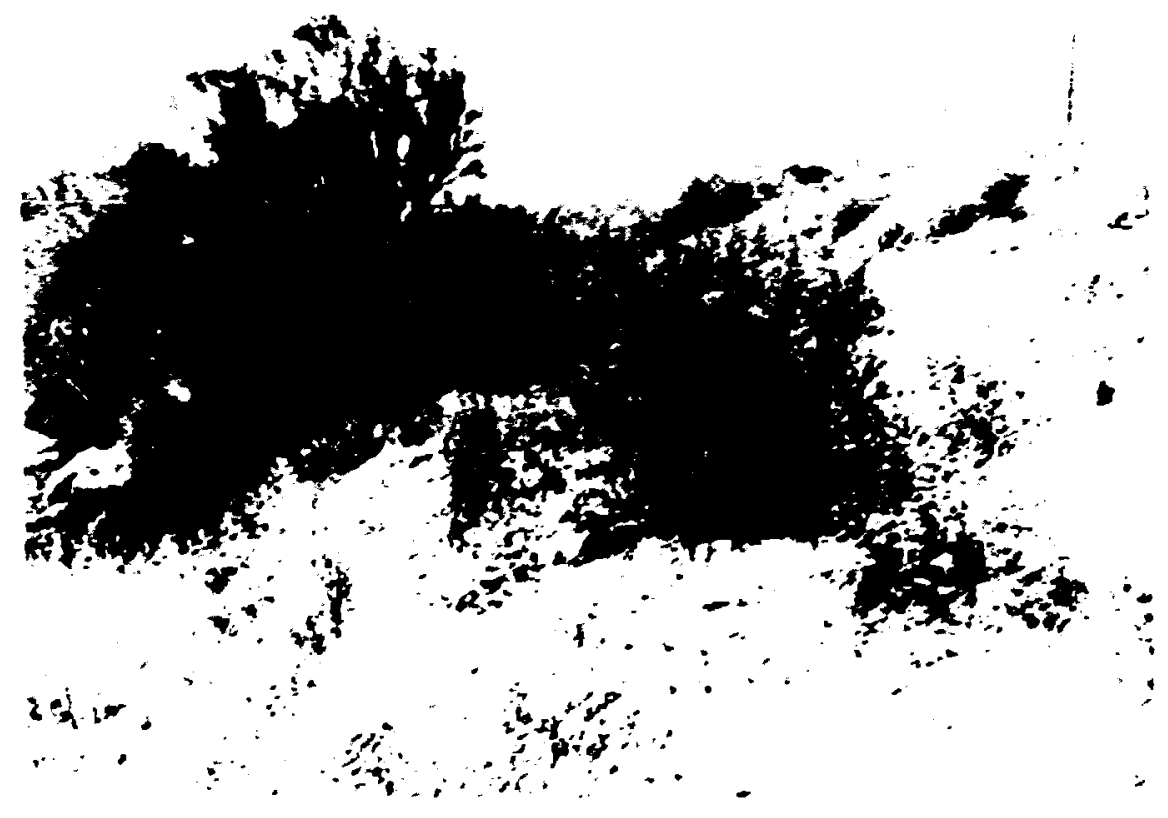

3. Br;an': Warn, Lnjirir, southea:t. 

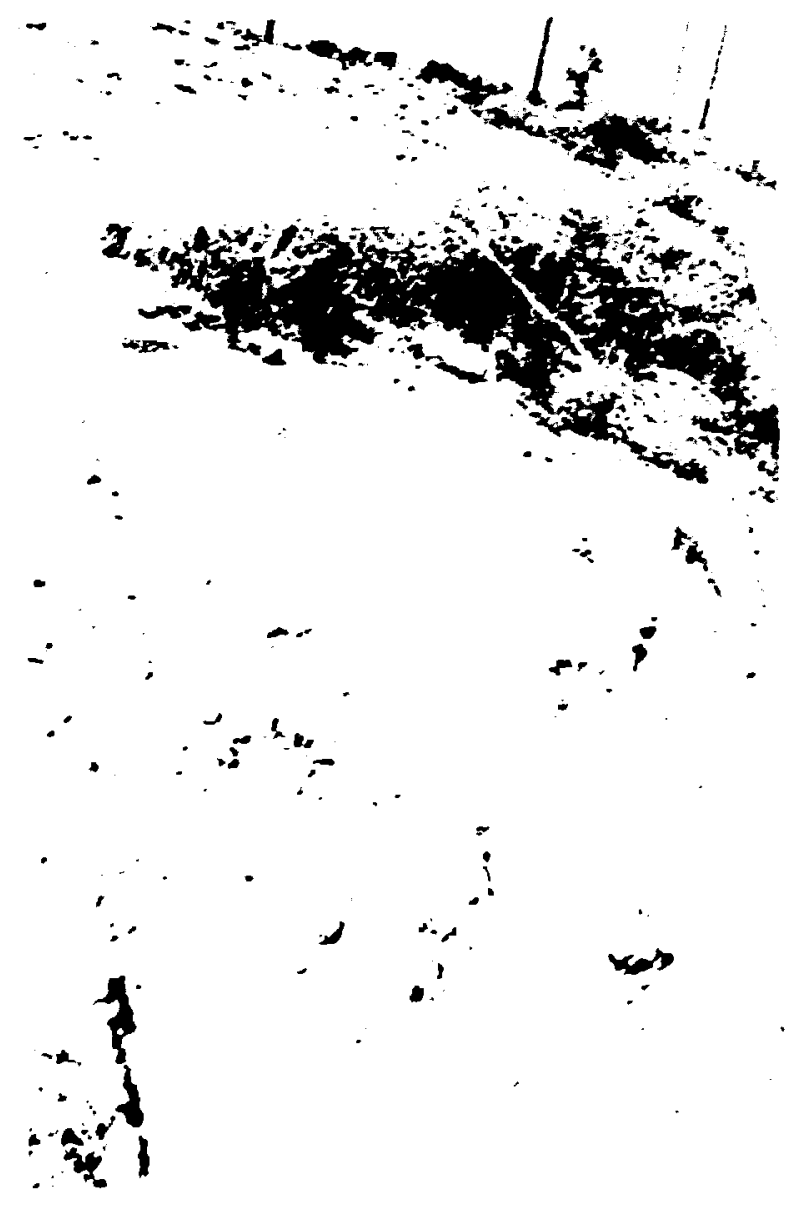

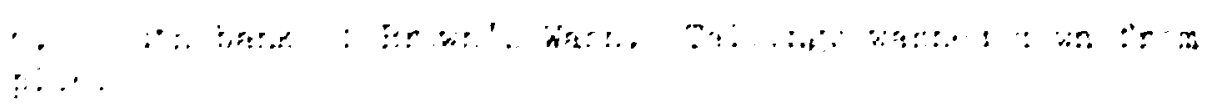




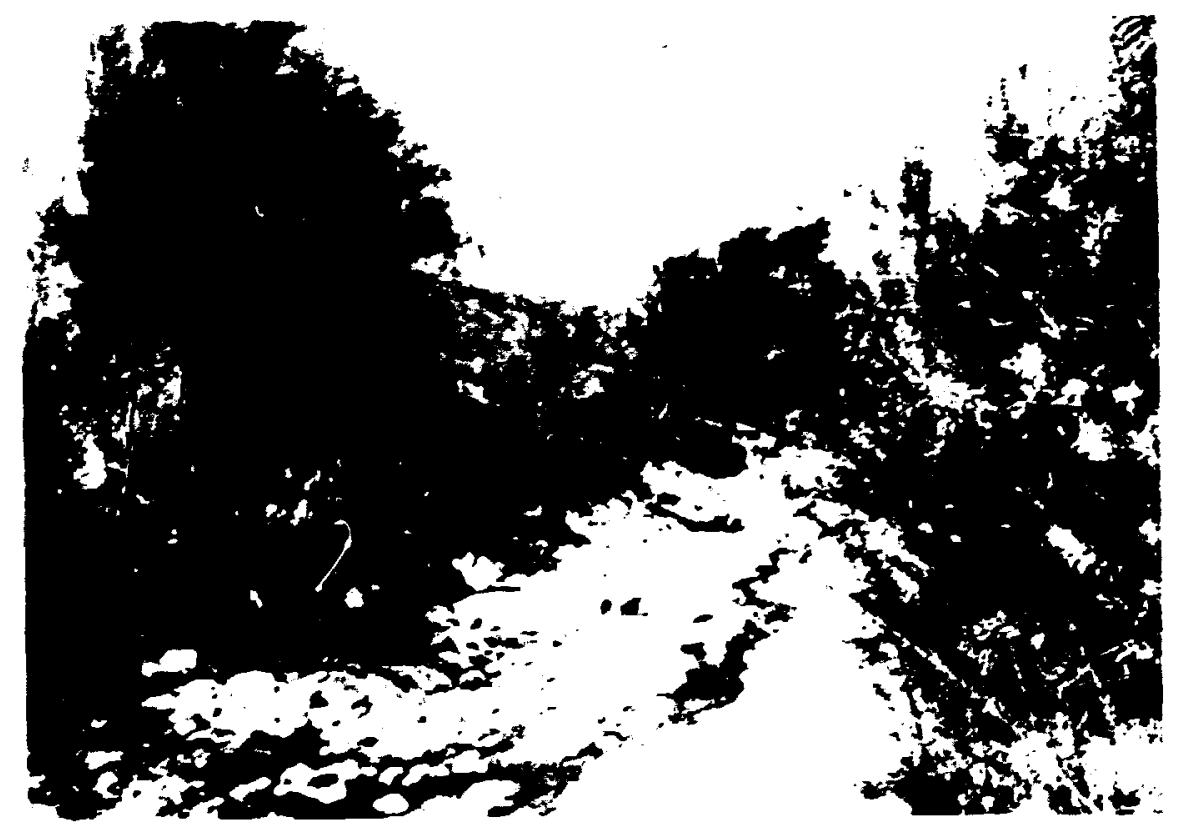

i. Brown's Wath. So irtso wert. 


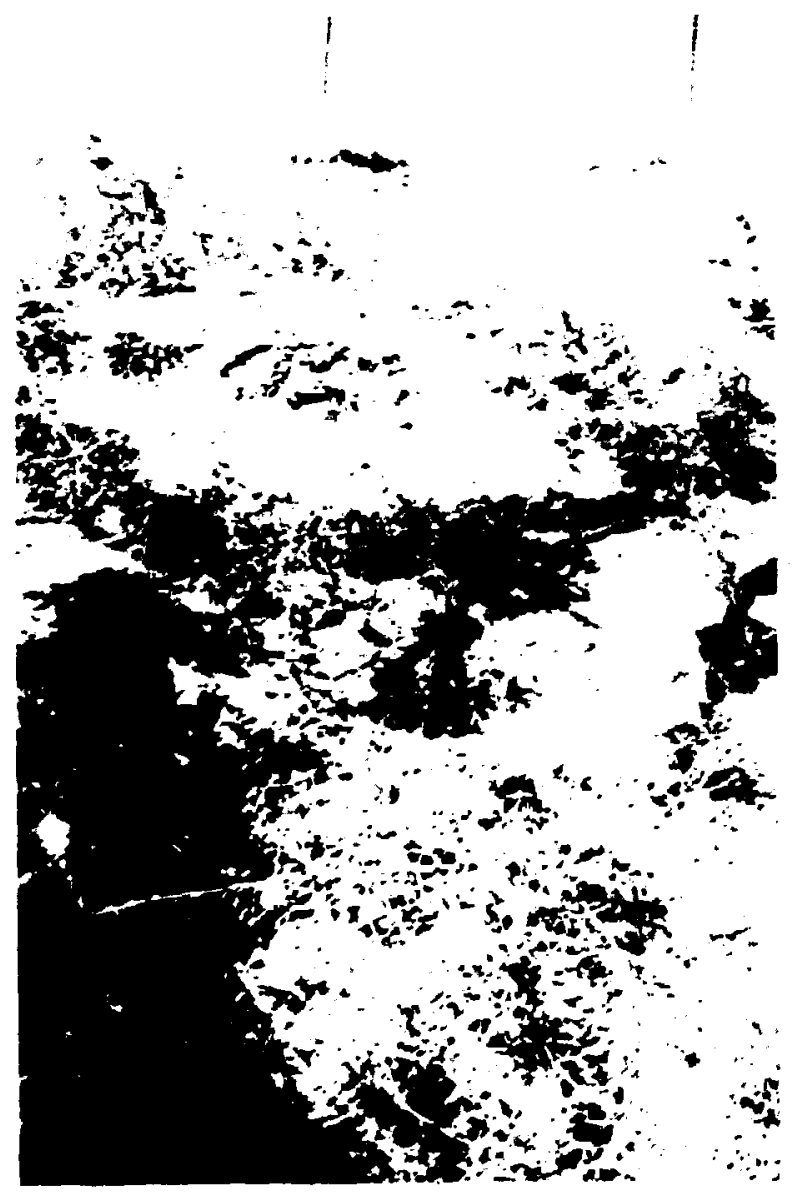

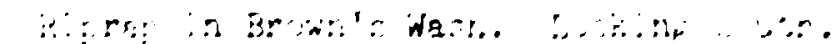


APPENOIX II

Soil Sampling Techniques

and

Radiological Measurements 
Soil Sampling and Measurement of Radionuclide Concentration as a Function of Depth in Soil

A monitoring and sampling procedure wic established for this project in conjunction with FB\&DU to measure the radionuclide concentration in soil as a function of depth. At each site, a set of $15-\mathrm{cm}$ (6-in.) diameter holes was drilled through the tailings and into the subsoil. A polyvinyl chloride (PVC) pipe $(7.6 \mathrm{~cm}$ o.d.), sealed on one end, was lowered into each. hole, and measurements were made of gamma-ray intensities as a function of depth. A $15-\mathrm{cm}$-long Geiger-Mueller tube shielded with a lead cover containing collimating slits was used for this purpose by lowering it inside the PVC pipe for measurements. Signals from this detector were counted using a portable scaler. 1

After gamma-ray vs depth profiles were determined, the position of the interface between tailings and subsoil was estimated. Once completed, the drilling rig was moved approximately $1.2 \mathrm{~m}(4 \mathrm{ft})$, and another hole was drilled to the interface level. Samples of soil core were then collected as a function of depth using a split-spoon sampler (each core section was $0.6 \mathrm{~m}$ lnn:y).

Most of the penetrating gamma radiation monitored is attributable to ${ }^{226} \mathrm{Ra}$ and its daughters. Therefore, a calibration factor for ${ }^{226} \mathrm{Ra}$ concentration was determined for the collimated gamma-ray probe by comparing the response of this unit (counts per unit time) with a measured value for the radium concentration (picocuries per gram) in several soil samples determined by a gamma-ray spectrometry technique. A leastsquares fit of FB\&DU data (first probe) from this comparison yields the equation

$$
R=0.528(C-16)
$$

For this case, $R$ is the ${ }^{226} R$ a activity in picocuries per gram and $C$ is the observed response of the collimated gamma-ray detector in counts per minute; there were 16 background counts per minute for the gamma-ray detector. 
The above expression was useful in estimating the overall distribution of radioactivity in the tailings as well as the total quantity of radium in the tailings area. Surface soil samples were obtained normally by removal of an approximately 3-cm-deep layer of scil from an area of about $25 \times 25 \mathrm{~cm}$. The same procedure was used to obtain samples $15 \mathrm{~cm}$ (6 in.) below the surface except that the top 15- $\mathrm{cm}$ layer of soil was discarded and the sample was removed from the next $3-\mathrm{cm}$ layer.

Each sample was aried for $24 \mathrm{hr}$ at $110^{\circ} \mathrm{C}$ in order tc remove moisture. The samples were then pulverized in a high speed rotary crusher having plates adjusted to provide particles no larger than $500 \mu \mathrm{m}$. The soil was dispensed into 25-ml polyethylene vials of the type used for liquid scintillation counting and sealed tightly. A soil sample normally consists of 12 of these vials. The net weight of the group of vials was measured to the nearest tenth of a gram.

The sealed sample vials were stored for a period sufficient to al low attainment of equilibrium between ${ }^{226} \mathrm{Ra}$ and its short-lived daughters. Radon-222, which has a radioactive half-life of 3.8 days, will reach the same activity as its long-lived parent, ${ }^{226} \mathrm{Ra}$, in about 30 days. The short-lived progeny of ${ }^{222} R n$ will have reached equilibrium within the same time. Determination of the activity of any of the daughters in the sample will reflect ${ }^{226}$ Ra activity. After equilibration of radon daughters, the 12 sample vials (or smaller number) were inserted into a sample carousel or hoider (Fig. II-1) that was placed on a $\mathrm{Ge}(\mathrm{Li})$ detector for counting as described in the section on gamma-ray spectrometry below.

\section{Field Laboratory Facilities and Equipment}

A 20-ft mobile laboratory van was used as a field office and for transporting instruments. This van contained an alpha spectrome,y counting system for air samples along with air sampling equipment; a Johnston Laboratory radon monitor complete with Lucas-type flasks and an evacuation manifold; gamma-ray detectors; miscellaneous electronic testing equipment; and standard calibration sources. A trailer-mounted, gasoline-powered $12 \mathrm{~kW}$ motor generator, pulled by the van, was used to 


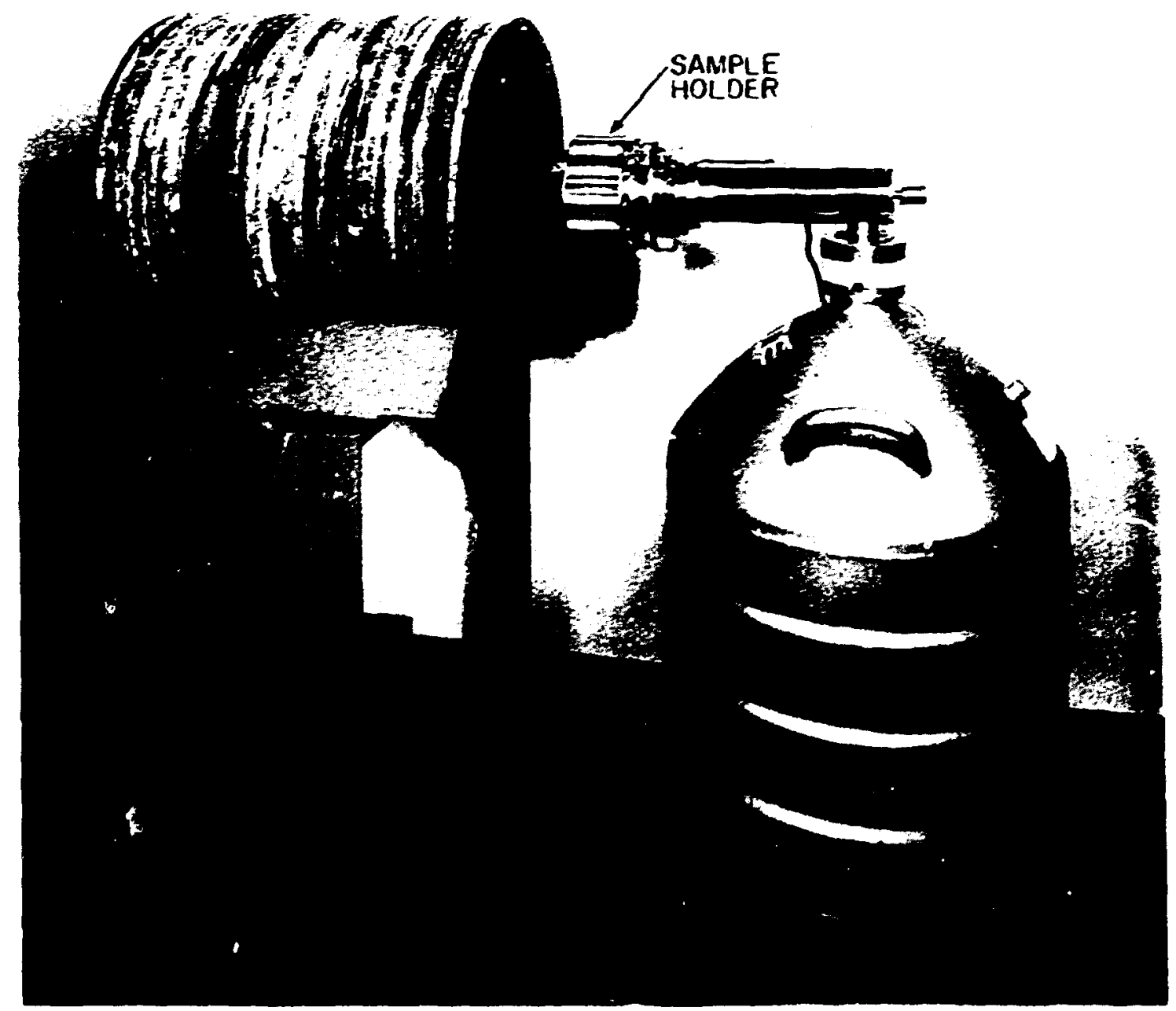

Fig. 11-1. Horizontal mounted Ge(Li) detector system used for counting soil samples (carousel-type sample holder is shown in its counting position). 
supply electrical power in remote locations. A voltage stabilizer was used to provide regulated power for instruments.

A second field laboratory used in the project was an $8 \times 35 \mathrm{ft}$ airconditioned semitrailer with running water, tools, and miscellaneous supplies. It served as an instrument calibration facility, office, and workshop. This trailer required electrical power from an external source. During most of this project, the trailer was parked in Grand Junction and was used as a temporary field office.

\section{Gamma-Ray Spectrometry Systems}

A Harshaw integral $3 \times 3$ in. NaI (TI) crystal, a high sensitivity detector, was used to scan all samples for a preliminary estimate of ${ }^{226}$ Ra activity. This detector was used in a "pickle barrel" type shield, lined with copper and cadmiuar to shield x-rays. Signals from the crystal were sorted by a computer-based (PDP-11) pulse-height analyzer. The computer was programmed to control all functions of the analyzer and counter, to analyze the data, and to print out a statistically weighted average of the ${ }^{226}$ Ra activity per unit mass. One advantage of this counting arrangement is that it permits quick sorting; samples can be scanned at the rate of about six per hour (minimum counting period is $5 \mathrm{~min}$ ).* An energy calibration of the NaI crystal and analyzer was obtained by standardizing with ${ }^{57} \mathrm{Co},{ }^{137} \mathrm{Cs}$, ana ${ }^{60} \mathrm{Co}$. An efficiency calibration was obtained through daily counting of a uranium standard $^{\dagger}(0.05 \%$ uranium mixed with dunite, particle size $=500 \mu \mathrm{m})$. Radium-226 is in equilibrium with the uranium, and this isotope and its daughters provide a source of gamma-ray lines for calibration.

*The principal reason for using this scanning system was to Estimate how much time would be required to count the samples with one of three high resolutions $\mathrm{Ge}(\mathrm{Li})$ gamma-ray spectrometers.

† Standard uranium sample obtained from the former Atomic Energy Commission New Brunswick Laboratory. 
Final data on the concentration of radionuclides in soil samples were determined by counting all samples with one of three high resolution $\mathrm{Ge}(\mathrm{Li})$ spectrometers. These high resolution counting systems consist of one horizontally mounted $50-\mathrm{cm}^{3} \mathrm{Ge}(\mathrm{Li})$ crystal positioned on a platform for movement into and out of a lead shield (Fig. II-1), and two vertically mounted detectors (Fig. II-2). The detector systems were used to obtain complete photon spectra of the soil samples. Signals from the horizontal $\mathrm{Ge}(\mathrm{Li})$ crystal were routed to a 4096-channel pulse height analyzer and signals from the other two $\mathrm{Ge}(L i)$ crystals were routed to two 2688 channel regions of a computer based pulse height analysis system. Sapples were counted for periods long enough to evaluate the ${ }^{226} \mathrm{Ra}$ concentration to a statistical accuracy of $\pm 5 \%$ or better. Spectra from the horizontally mounted $\mathrm{Ge}(L \mathrm{i})$ detector were recorded on magnetic tape and stored for later analysis using the ORML IBM computer system. *

The computers were programed to sort out pei'ss from ${ }^{232}$ Th daughters including the 909 and $967 \mathrm{keV}$ peaks from ${ }^{228} \mathrm{AC}$, the $239 \mathrm{keV}$ from $212 \mathrm{pb}$, and the 2614 and $583 \mathrm{keV}$ peaks from ${ }^{208} \mathrm{Tl}$. These data permitted measurements of the ${ }^{232} \mathrm{Th}$ concentration and data are reported for many of the samples.

Energy calibration of the $\mathrm{Ge}(\mathrm{Li})$ detectors was controlled through the use of isotopic sources of ${ }^{57} \mathrm{Co},{ }^{22} \mathrm{Na},{ }^{137} \mathrm{Cs},{ }^{8: 0} \mathrm{Cc},{ }^{88} \mathrm{Y}$, and ${ }^{40} \mathrm{~K}$. A calibration check was completed each day prior to beginning sample counting. In order to maintain linearity of the ADC's, a spectrum stabilizer was utilized. This instrument can be adjusted so that two individual photo., energies are detected and maintained in two channels at separate ends of the scale. These two calibration points helped maintain a. energy span of $1 \mathrm{keV}$ per channel. Efficiency calibration was obtained through the use of the same uranium ore standard samples as for the NaI crystal. An analysis of the counting data was accomplished

*Spectra from the two vertically mounted Ge(Li) detectors were stored on magnetic tape for record purposes, but were analyzed immediately using a Tennecomp Model TP-5/11 computer-based analyzer. 


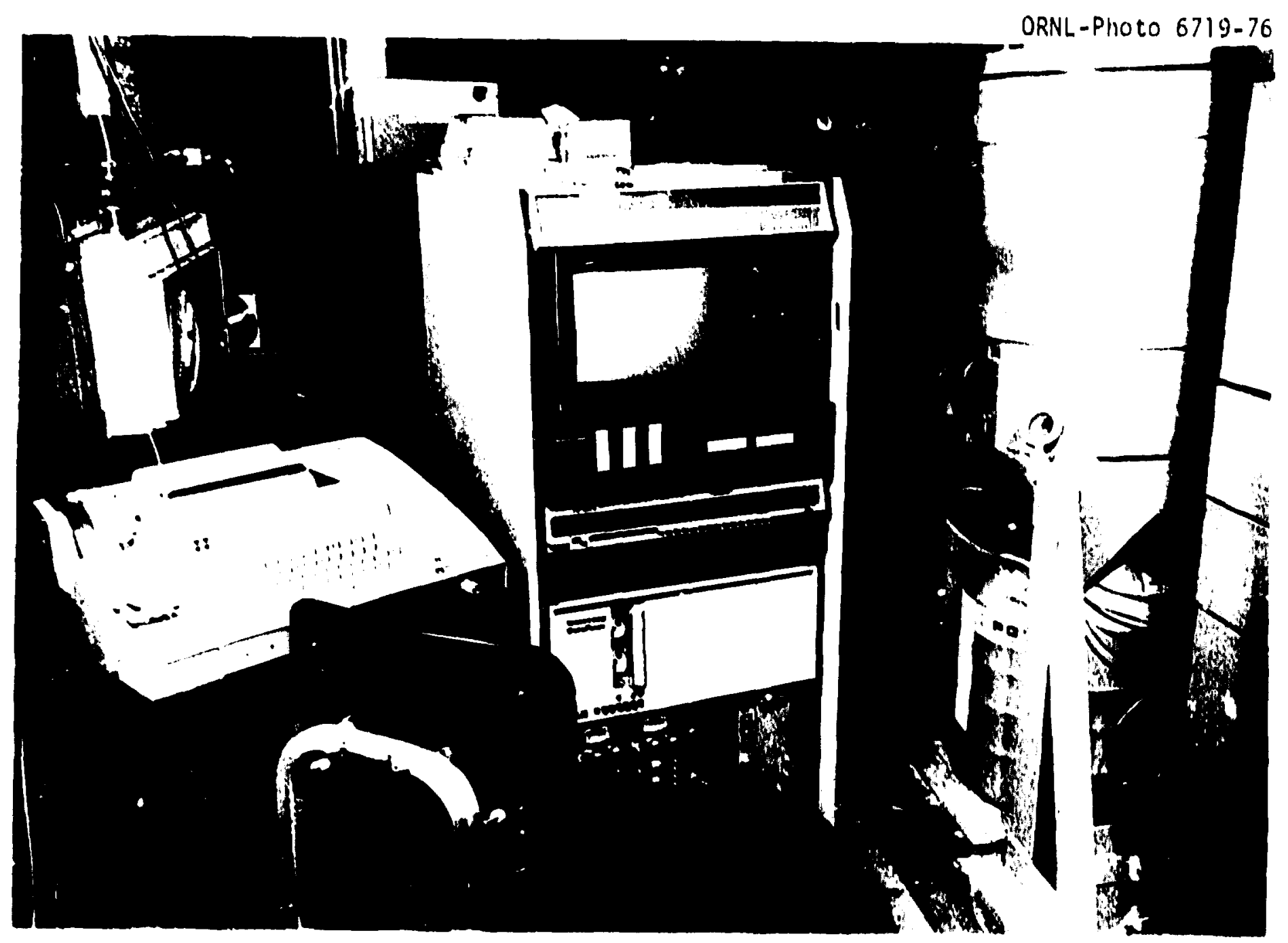

Fig. II-2. Computer based multichannel analyzer and one of three Ge(LI) counting systellis. 
through a linear least-squares fitting routine. Het adjusted areas under photo peaks of interest were compared with an extensive radionuclide library. 2 Data from the computer were presented for each radionuclide as a weighted mean with standard deviation.

\section{External Gama-Ray Detector}

A gama radiation survey was made on and around the mill site and tailings pile. The instrument used for these measurements was a "Phil" gama-ray dosimeter. ${ }^{3}$ The basic unit was a $15-\mathrm{cm}$ - (6-in.) long 30-ng/ $\mathrm{Cm}^{2}$ glass-walled organic-filled Geiger-Mueller (G-M) tube with an energy compensation shield ade of tin and lead. Pulses from this unit were counted with a battery-porered portable scaler. Typically, G-M counters are not used for dosimeters because of a peaked response at low photon energies. However, perforated layers of tin $(1.0 \mathrm{~m})$, and lead $(0.1 \mathrm{~mm})$, were used as an energy compensation filter to flatten this peaked response at photon energies below about $200 \mathrm{keV}$. Sealed sources of ${ }^{137} \mathrm{Cs}$ and ${ }^{226} \mathrm{Ra}$ were used for calibration. It was found that the response of this detector was: $1 \mathrm{aR} / \mathrm{hr}=3400$ counts $/ \mathrm{min}$.

For each gana-ray-exposure rate measurement, at least three 1-min counts were recorded. The mean of these readings (less instrument background) was used to determine the exposure rate to external gama rays.

\section{Radon Daughter Sampler*}

Radon daughter concentrations were asured with a sampling and counting instrument which has been in use at ORNL for several years, 4 and it was also used to make some comparative measurements in the remedial action program in Grand Junction. 5 The filler counter for this sampling device, shown in Fig. II-3, utilized a modified gas flow alpha

*This section and the following section contain descriptions of devices and methodologies typically used in the radiological surveys of milling facilities. They are included in each report in this series. However, in some instances, the measurements were not possible. 


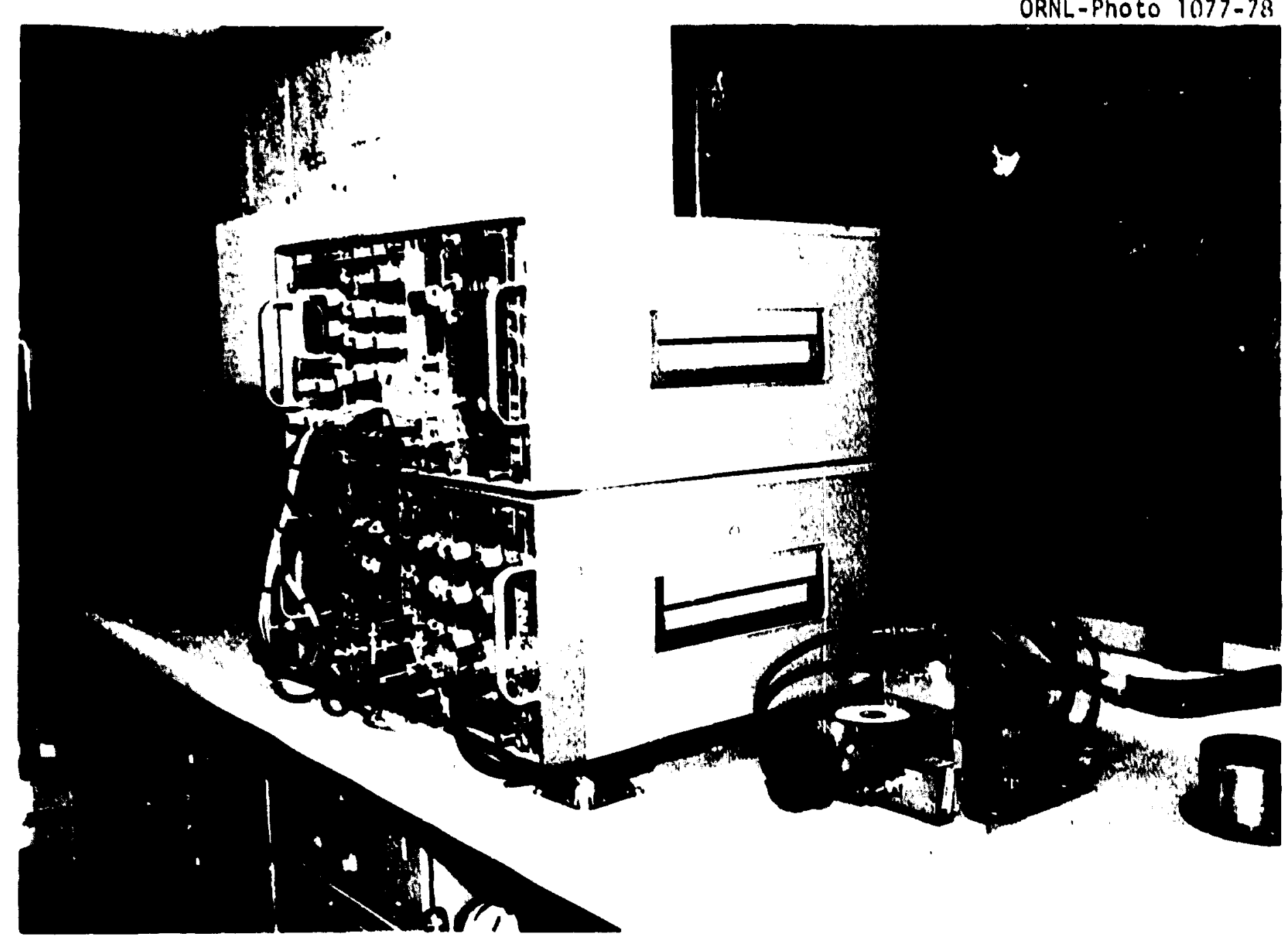

Fig. I1-3. System used for measurement of radon daughter concentrations. 
counter for housing a $450-\mathrm{man}^{2}$ silicon diode. Normally, this type detector is operated in a vacuu chamber. However, in this case, it was found that by flowing helium at atmospheric pressure through the assembly, absorption of alpha particles is small relative to absorption in air. Alpha particle pulses were recorded with a 100-channel analyzer. A swall 228Th alpha source standard was used for standardizing the energy scale. Air that was monitored for radon daughters was sampled at a rate of 12 to 14 liters/min. An absolute calibration of the airtlow was provided through a comparison of the sampler's mass flow meter and a wet test weter. Samples were norally collected for $10 \mathrm{~min}$, and the first count of the filter was started at 2 min after removal of the sample and continued for 10 min. For this case, a determination was made of the number of counts due to the decay of 218Po (RaA) and 214Po ( $\left.R a C^{\prime}\right)$. A second count was started 15 min after removal of the sample and continued for $15 \mathrm{~min}$. In this case, counts were recorded from the decay of 214 po. Data from the counter were stored in a pulse height analyzer and reduced by computer. The code for this analysis is explained in detail elsewhere. ${ }^{6}$ Results of the analysis of data using this code were presented as concentrations of RaA, RaB, and RaC'. In addition, a value for the working level concentration was also provided along with an estimate of the error associated with each reported value.

\section{Radon Monitor}

The instrument used by ORNL to measure radon concentrations in air consisted of 95-ml Lucas chambers and a readout unit.* Each chamber was evacuated to approximately $1 \mathrm{mg} \mathrm{Hg}$ and then opened to atmosjineric pressure in the area where a radon measurement was required. No filtration was used for sampled air. The short-lived daughters of radon drawn into the chamber were allowed to decay for 3 to $4 \mathrm{hr}$ prior to counting the flask. Comparison of the results from this instrument and the radon

*LLRC-2 Low Level Radon Counting System manufactured by Johnston Laboratories, Inc., Baltimore, Md. 
progeny monitor provided an estimate of the degree of equilibriun between radon and its daughters in the selected locations where air samples were taken. 


\section{APPENDIX II REFERENCES}

1. J. H. Thorngate and J. E. Parks, "A Portable Scaler," Featth Phys. 12, 385-393 (1965).

2. J. F. Emery and F. F. Dyer, "Multi-Element Determination in Environmental Neutron Activation Analysis Using MONSTR," Iroseedings of the Second Intemational Conference on Ireciear llethods and Exuimonmentat Research, CONF-740701, held at the University of Missouri, Columbia, Mo., July 29-31, 1974.

3. E. B. Hagner and G. S. Hurst, "A Geiger-Mueller a-Ray nosimeter with Low Neutron Sensitivity," Hextth Phic. 5, 20-26 (1961).

4. P. T. Perdue, H. H. Sininaugh, J. H. Thorngate and J. A. Auxier, "A Convenient Counter for Measuring Alpha Activity of Smear and Air Samples," Heazth Phus. 26, 114-116 (1974).

5. G. D. Kerr, "Measurements of Radon Daughter Concentrations in Air," pp. 202-207 in Dosimetry for Humar Exposures and Radiological Imyast, ORNL-497n (July 1974).

6. G. D. Kerr, Measurement of Ixdon Progeny Concentrations in Air by Alpha-Particle Spectrometri, ORNL-TM-4924 (July 1975). 
APPENDIX III

Water Sampling and Analysis

Water sampies are obtained at appropriate points on and z.round the mill site, labeled and stored for later analysis. Each sample is centrifuged and filtered through a $0.45-\mu m$ filter to remove suspended solids. The samples are then analyzed by radiochemical techniques as descril ed in this appendix. 
Procedure for the Sequential Determination of ${ }^{226} \mathrm{Ra},{ }^{230} \mathrm{Th}$, and $210 \mathrm{~Pb}$ in Water from Uranium Mill Tailings Sites

P. M. Lantz

Health and Safety Research Division

Oak Ridge Kational Laboratory

Oak Ridge, Tennessee

\subsection{Radium-226}

1.1 Filter the 21.0 liter water sample using a vacuum flask and \#42 Whatman filter paper to remove suspended particles.

1.2 Reduce the volume of the water sample, to which $10 \mathrm{ml}$ of concentrated $\mathrm{HNO}_{3}$ has been added, to less than $250 \mathrm{ml}$ by evaporation.

1.3 Transfer the solution to a 250-m1, long-neck, tapered-joint, flat-bottom Pyrex boiling flask. Insert a Teflon-coated magnetic stirring bar. Add $37 \mathrm{ml}$ of concentrated $\mathrm{HNO}_{3}$ to make the final concentration $3: \because$. Insert the modified, female, tapered joint with gas diffuser and side arm with stopcock. Seal off the gas inlei and close the stopcock to assure containment of ${ }^{222} \mathrm{Rn}$ in the flask. Store for at least 30 days to await attainment of ${ }^{226} \mathrm{Ra}^{222} \mathrm{Rn}$ equilibrium.

1.4 Next, connect the 250-mi de-emanation flask to a helium source and the radon trapping system. Attach an evacuated Lucas chamber. Flush the system with helium gas while bypassing the flask. Stop the gas flow. Immerse the unfired Vycor radon concentrator in a liquid nitrogen bath. Be sure the upstream exit for helium gas is open. Start the magnetic stirrer. Open the flask side arm stopcock to the system and start helium gas flowing through the liquid at a rate not to exceed 2.8 liters/hr. The radon-helium stream is dried and stripped of organic condensable components by $\mathrm{KOH}$ and ascarite traps. Radon is condensed on the Vycor at liquid nitrogen temperature and thus separated from the helium gas carrier. 
1.5 Stop the de-emanation process after $30 \mathrm{~min}$. Having shut off the gas flow, close the helium exit. Isolate the radon trap and the evacuated Lucas chamber from the remainder of the system via stopcocks.

1.6 Open the Lucas chamber stopcock and remove the liquid nitrogen from the radon trap to allow the gaseous radon to diffuse into the chamber. To hasten the diffusion, the trap may be gently flamed.

1.7 Bypassing the flask, use a controlled stream of helium to flush residual radon into the Lucas chamber until near atmospheric pressure has been reached. Stop the gas flow and close the stopcock on the Lucas chamber.

1.8 After a delay of 3.0 to $3.5 \mathrm{hr}$ to permit the ${ }^{222} \mathrm{Rn}$ to reach equilibrium with its daughters, place the Lucas chamber over a photomultiplier tube and count the gross alpha for $30 \mathrm{~min}$.

1.9 Subtract the Lucas chamber background, counted under the same conditions, from the gross count. Divide the net count by three to obtain the ${ }^{222} \mathrm{Rn}$ count at that time. Correct the count for time elapsed since de-emanaticin was terminated and the efficiency of the Lucas chamber for converting alpha discharges to scintillations ( $285 \%$ ). Report the ${ }^{226}$ Ra in equilibrium with ${ }^{222}$ Rn as picocuries per liter.

\subsection{Thorium-230}

2.1 Transfer one-half of the water sample remaining from the radon de-emanation process $\left(3 \mathrm{HHNO}_{3}\right)$ to a Pyrex beaker for volume reduction on a magnetic stirrer hot plate.

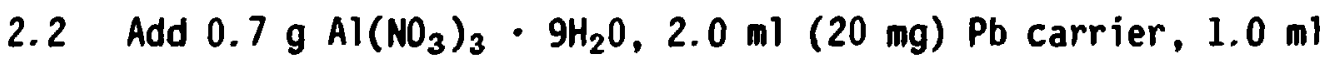
(20.9 $\mathrm{mg}$ ) Bi carrier and 5,000 to $10,000 \mathrm{cpm}$ of ${ }^{234} \mathrm{Th}$ tracer to the water sample before reducing the volume to approximately $20 \mathrm{ml}$.

2.3 Should the sample solution contain undissolved salts, separate liquid and solios by use of centrifuge. Dissolve the 
solias by heating with a minimum volume of distilled water or dilute $\mathrm{HNO}_{3}$. Combine the dissolved solid with the original supernate. Should silicic acid form in the solution during volume reduction, as evidenced by its deposition on the beaker walls, cool the solution to room temperature and centrifuge. Add an equal volume of concentrated $\mathrm{HNO}_{3}$ to the supernate. Wash the solids with a small volume $(5.0 \mathrm{ml})$ of $8 " \mathrm{HNO}_{3}$ and centrifuge. Combine the wash with the adjusted supernate. Discard the solids. Keep the solution cool in an ice bath during precipitation of hydroxides with an excess of ammonium hydroxide to minimize the formation of silicic acid from dissolved silicates. Let stand 5 to 10 min. Centrifuge, pour off the supernatant liquid, and wash the precipitate with dilute ammonium hydroxide. Discard the supernatant and wash liquids. Dissolve the solids in 10-20 ml of $8 \mathrm{MHNO}_{3}$. Shculd the solution contain suspended silicic acid, centrifuge, wash the solids with $5 \mathrm{ml}$ of $8: \because \mathrm{HNO}_{3}$ and combine the supernatant liquids. Discard the solids.

2.4 Transfer the $8 \mathrm{MHNO}$ solution to a conditioned Dowex $4 \times 1$ anion exchange column $5 \mathrm{~mm}$ i.o. $\times 10 \mathrm{~cm}$ long ( $2.0 \mathrm{ml}$ vol.). The column is conditioned by passing through it at least 5 column volumes $(10 \mathrm{ml})$ of $8 \because \mathrm{HNO}_{3}$. The anion-complexed thorium adsorbs on the resin column to the exclusion of the cations. Wash the column with $10 \mathrm{ml}$ of 8 !! HNO $\mathrm{H}_{3}$ to remuve residual bismuth. Combine the effluent and wash solutions, and save them for lead and bismuth recovery.

2.5 Strip the thorium from the column with $5.0 \mathrm{ml}$ of distilled water followed by $10 \mathrm{ml}$ of $6: \because \mathrm{HCl}$.

2.6 Convert the chloride to the nitrate by adding an excess of $\mathrm{HNO}_{3}$ and reducing the solution to near dryness on a hot plate. Dissolve the solids in $5.0 \mathrm{ml}$ of $0.1 \% \mathrm{HNO}_{3}$.

2.7 Transfer the $0.1 \mathrm{H} \mathrm{HNO}_{3}$ solution to a conditioned Dowex $50 \times$ $1 \mathrm{~mm}$ cation exchange $2.5 \mathrm{~mm}$ i.d. $\times 7 \mathrm{~cm}$ long ( $20.4 \mathrm{ml}$ vol.). The column is conditioned by passing $5.0 \mathrm{ml} 8 \mathrm{M} \mathrm{HNO}_{3}$ through 
it and then washing it free of excess acid with distilled water as indicated by $1 \mathrm{itmus}$ paper.

2.8 Wash the coluan with $5.0 \mathrm{ml}$ of $2 \mathrm{M} \mathrm{HCl}$ to remove traces of bismuth and other weakly bound cations.

2.9 Strip the thorium with $5.0 \mathrm{ml}$ of $8 \mathrm{M} \mathrm{HNO}$ and reduce the volume of the solution to a few drops by evaporation.

2.10 Transfer the solution with a suitable pipette onto a 2-in. stainless-steel disc supported on a hot plate by a steel washer 0.75 in. i.d. $\times 1.5$ in. $0 . d$. Dry slowly to minimize the deposit area at the center of the disc. Fire the disc to red heat with a gas torch to remove carbonaceous materials.

2.11 Determine the thorium yield by counting the ${ }^{234}$ Th beta with an end window counter and compare it with a mounting of like count of the ${ }^{234}$ Th tracer used in the analysis.

2.12 Determine the ${ }^{230} \mathrm{Th}$ alpha disintegrations per minute (dpm) by pulse-height analysis using a diode pickup in a helium atmosphere. Compare the counts of ${ }^{230}$ Th alpha in the sample with those in a ${ }^{230}$ Th standard mounting whose dpm is known.

2.13 To correct for the contribution of ${ }^{230} \mathrm{Th}$ which may be in the ${ }^{234}$ Th tracer, pulse analyze the ${ }^{234}$ Th mounting. Subtract the contribution from the tracer after correcting for yield to obtain the net 230 Th content of the water sample.

2.15 Calculations

$$
{ }^{230} \operatorname{Th}(p C i / l i \text { ter })=\frac{A B}{\text { CDEF }}
$$

where

$$
\begin{aligned}
& A=\text { Water sample net alpha }(\mathrm{cpm}) \\
& B=230 \mathrm{Th} \text { standard }(\mathrm{dpm}) \\
& C=230 \mathrm{Th} \text { standard }(\mathrm{cpm}) \\
& D=\text { Fraction of } 234 \mathrm{Th} \text { tracer recovered } \\
& E=\text { Volume of sample }(l i t e r) \\
& F=2.22 \mathrm{~d} /(\mathrm{m} \cdot \mathrm{pii})
\end{aligned}
$$


3.0 Lead-210

3.1 Evaporate the Dowex $4 \times 1$ effluent and wash from Step 2.4 to 220 ml. Cool and slowly add amonium hydroxide, while stirring in an ice bath, until hydroxide precipitation barely starts. Add 1 to 2 drops of concentrated $\mathrm{HNO}_{3}$ to each $10 \mathrm{ml}$ of solution to give an acidity of 0.2 to $0.4 \%$.

3.2 Slowly bubble $\mathrm{H}_{2} \mathrm{~S}$ through the chilled solution to precipitate metal sulfides. Let the mixture stand 10 to 15 min and centrifuge. Discard the supernate. Wash the sulfides with 5 to

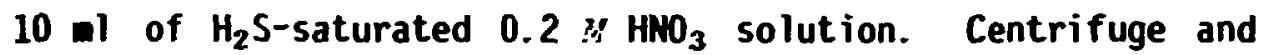
discard the wash.

3.3 Dissolve the sulfide precipitate in a minimum of concentrated $\mathrm{HNO}_{3}$ by heating in a hot water bath. Dilute with 5 to $10 \mathrm{ml}$ of distilled water and filter out the suspended sulfur on \$42 Whatwan filter paper. Wash out the centrifuge tube and filter with 5 to $10 \mathrm{ml}$ of distilled water.

3.4 Transfer the solution to a centrifuge tube and precipitate the hydroxides with an excess of ammonium hydroxide. Digest 10 min in a hot water bath. Cool, centrifuge, and wash the precipitate with 5 to $10 \mathrm{ml}$ of dilute $\mathrm{NH}_{4} \mathrm{OH}$. Discard the supernatant and wash liquids.

3.5 Dissolve the hydroxides in a minimum of concentrated $\mathrm{HNO}_{3}$ and dilute to $10 \mathrm{ml}$. Add $0.5 \mathrm{ml}$ of concentrated $\mathrm{H}_{2} \mathrm{SO}_{4}$ to precipitate $\mathrm{PbSO}_{4}$. Digest 15 min in a hot water bath, cool, centrifuge, and wash the $\mathrm{PbSO}_{4}$ with distilled water. Save the supernatant and wash liquids for bismuth recovery.

3.6 Transfer the $\mathrm{PbSO}_{4}$ slurry onto a tared \#42 Whatman filter paper disc which is supported by the perforated fixed plate of a Hirsch funnel. Dry the $\mathrm{PbSO}_{4}$ and paper with ethyl alcohol followed by ethyl ether.

3.7 Weigh the filter paper and $\mathrm{PbSO}_{4}$ to determine the yield of $210 \mathrm{~Pb}$. Store the $210 \mathrm{PbSO}_{4}$ sample for 30 days to allow the $210 \mathrm{~Pb}$ to reach equilibrium with its $210 \mathrm{Bi}$ daughter. The $210^{\circ} \mathrm{Bi}$ beta is counted in a low-level gas-proportional counter with a 
1-mil-thick polystiyrene cover to shield out any stray alpha emissions.

3.8 Add pellets of $\mathrm{NaOH}$ to the bismuth solution from Step 3.5 to precipitate bismuth hydroxide. Digest for $10 \mathrm{~min}$ in a hot water bath, cool, and centrifuge. Wash the precipitate with $10 \mathrm{ml}$ of distilled water. Discard supernatant and wash liquids.

3.9 Dissolve the solids in a minimum of $\mathrm{HNO}_{3}$. Add 3-4 drops of concentrated $\mathrm{HCl}$ and dilute to $\sim 40 \mathrm{ml}$ with hot distilled water to precipitate $\mathrm{BiOCl}$. Digest for $\sim 45$ min in a hot water bath or until the precipitate has settled.

3.10 Pour the hot supernatant liquid through a tared \#42 Whatman filter paper supported by a perforated, fixed-plate, Hirsch funnel. Slurry the BiOCl onto the filter paper disc with small portions of hot distilled water. By means of a stirring rod, guide the deposit to the center of the disc. Ory with ethyl alcohol and ethyl ether.

3.11 Weigh the BiOCl and filter paper in order to determine yield.

3.12 Count the 5.01 day $210_{B i}$ beta, which is in equilibrium with $210 \mathrm{~Pb}$, in a low-level, gas-proportional counter. The counting efficiency of the counter is determined by counting several similar mountings having known $210 \mathrm{Bi}$ disintegratior rates, with varying weights of $\mathrm{BiOCl}$ from which a calibration curve is constructed.

3.13 Refer to the calibration curve and convert cpm to dpm by means of an efficiency factor for the weight of sample in question.

3.14 Calculation

$$
210 \mathrm{~Pb} \rightarrow 210^{\circ} \mathrm{Bi}(\mathrm{PCi} / 1 \text { iter })=\frac{\mathrm{AB}}{\mathrm{CDEF}}
$$

where

$$
\begin{aligned}
A= & \text { Beta count minus background }(\mathrm{cpm}) \\
B= & \text { Correction for decay from } \mathrm{Pb} \text { separation time } \\
& \text { to counting time }
\end{aligned}
$$


$C=$ Counter efficiency

$D=$ Fraction of $B i$ recovered

$E=$ Volune of sample (liter)

$F=2.22 d /(\mathrm{a}-\mathrm{p} C \mathrm{i})$

\subsection{Reagents}

4.1 Aluminum nitrate.

4.2 Lead carrier, $10 \mathrm{mg} / \mathrm{ml}$. Dissolved $8.0 \mathrm{~g} \mathrm{~Pb}\left(\mathrm{MO}_{3}\right)_{2}$ in dilute $\mathrm{HNO}_{3}$ and dilute to 500 wl with water.

4.3 Bismuth carrier, $20.9 \mathrm{mg} / \mathrm{ml}$. Dissolve $5.225 \mathrm{G}$ bismuth metal in concentrated $\mathrm{HMO}_{3}$ and dilute to $250 \mathrm{ml}$ with water.

4.4 Thorium tracer, ${ }^{234}$ Th. Pretreat a $30 \%$ Adogen 364-Xylene solution by extracting it with an equal volume portion of $2 \mathrm{MHWO}_{3}$ for $2 \mathrm{~min}$. Dissolve $5.0 \mathrm{~g}$ of iecently depleted ${ }^{238} \mathrm{U}$ (as $\mathrm{U}_{3} \mathrm{O}_{8}$ ) in $2 \% \mathrm{HNO}_{3}$. Extract the thorium and uranium with an equal volume of pretreated $30 \%$ Adogen 364-Xylene in a separator flask by hand shaking at least 2 min. Separate phases and strip thorium frim the solvent. with 10 ml of $10: \mathrm{HCl}$. Convert the chloride solution to $2 \mathrm{MHNO}_{3}$ solution for a repeat extraction with solvent to remove traces of uranium. The second $10: \mathrm{HCl}$ strip is again converted to the nitrate for counting the ${ }^{234} \mathrm{Th}$ beta on a stainless steel disc. The mounting should be examined in a pulse-height alpha analyzer for the presence of ${ }^{230} \mathrm{Th}$. Should the ${ }^{230} \mathrm{Th}$ level be significant, then another source of depleted ${ }^{238} \mathrm{U}$ should be sought, or alternatively extract the ${ }^{234} \mathrm{Th}$ from a batch of ${ }^{238} \mathrm{II}$ from which the thorium had been extracted 1 to 2 months previously.

4.5 Anmonium hydroxide, concentrated.

4.6 Nitric acid, concentrated.

4.7 Hydrochloric acid, concentrated.

4.8 Sodium hydroxide pellets.

4.9 Sulfuric acid, concentrated. 
4.10 Hydrogen sulfide gas.

4. 11 Dowex $4 \times 1$ and Dowex $50 \times 1$ exchange resins.

\subsection{Apparatus}

5.1 Radon de-enanation train witt: radon concentrator ${ }^{\star}$ and Lucas chamber.

5.2 Radon photomultiplier counter.

5.3 Hodified ${ }^{t}$ 250-al, flat-bottom, boiling flasks.

5.4 Other counting equipwent--G-M beta counter; low-level, gasproportional beta counter; pulse-height spectral alpha analyzer.

5.5 Stainless-steel alpha counting discs.

5.6 Laboratory centrifuge.

5.7 Pyrex centrifuge tubes, $50 \mathrm{ml}$.

5.8 Beakers, assorted.

5.9 Ion exchange columns.

5.10 Dowex $4 \times 1$ and Dowex $50 \times 1$ exchange resins.

5.11 Hirsch fixed plate funnel.

*The radon concentrator consists of a $20-\mathrm{cm}-$ long $U$-tube constructed from $6 \mathrm{mod}$. Pyrex glass tubing. Ten centimeters of the U-section is filled with 20 to 40 in. unfired Vycor which has a large surface to volue ratio. When the tube is imersed in liquid nitrogen and radonladen helium gas passes through the tube, the condensable radon adheres to the Vycor surface. The stripped helium gas exits the system. Upon removal of the coolant the radon vapor diffuses through 10 to $15 \mathrm{~cm}$ of capillary tubing to the evacuated Lucas chamber. Flushing the U-tube and attached capillary tubing with 20 to $30 \mathrm{ml}$ of helium transfers essentially $100 \%$ of the radon to the Lucas chamber. Since the efficiency of Lucas chambers for counting alphas may vary from 75 to $85 \%$, it is necessary to calibrate each chamber with an equilibrated ${ }^{228}$ Ra standard solution.

The radium-radon equilibrating flask consists of a flat-bottom 250-nl boiling flask with a iemale $24 / 40$ tapered joint. A saber-type sintered glass gas diffuser is sealed into a male $24 / 40$ taper joint section so that when it is inserted in the flask it will extend well into the equilibrating solution. A suitable inlet gas connection is provided on the opposite end of the diffuser tube. Onto the shoulder of the male $24 / 40$ joint is sealed a short length of small bore ( $5 \mathrm{~mm}$ i.d.) glass tubing with a glass stopcock terminating with a connector suitable for hooking up with the radon trapping system. 